\title{
Review \\ Oral Immune-Related Adverse Events Caused by Immune Checkpoint Inhibitors: Salivary Gland Dysfunction and Mucosal Diseases
}

\author{
Yoshiaki Yura * and Masakazu Hamada
}

check for updates

Citation: Yura, Y.; Hamada, M. Oral Immune-Related Adverse Events Caused by Immune Checkpoint Inhibitors: Salivary Gland Dysfunction and Mucosal Diseases. Cancers 2022, 14, 792. https:// doi.org/10.3390/cancers14030792

Academic Editor: Shaheen Khan

Received: 25 December 2021

Accepted: 2 February 2022

Published: 4 February 2022

Publisher's Note: MDPI stays neutral with regard to jurisdictional claims in published maps and institutional affiliations.

Copyright: (c) 2022 by the authors. Licensee MDPI, Basel, Switzerland. This article is an open access article distributed under the terms and conditions of the Creative Commons Attribution (CC BY) license (https:// creativecommons.org/licenses/by/ $4.0 /)$.

\author{
Department of Oral and Maxillofacial Surgery, Osaka University Graduate School of Dentistry, Suita, \\ Osaka 565-0871, Japan; hmdmskz@dent.osaka-u.ac.jp \\ * Correspondence: narayura630@gmail.com
}

Simple Summary: The antitumor effect of immune checkpoint inhibitors (ICIs) such as antibodies against CTLA-4, PD-1, and PD-L1 is higher than that of conventional chemotherapy and is durable, improving the survival of patients with advanced head and neck squamous cell carcinoma (HNSCC). However, this therapy reduces the immune tolerance state and allows antitumor cytotoxic CD8 ${ }^{+} \mathrm{T}$ cells to attack normal cells expressing self-antigens that cross-react with tumor antigens, and so it can induce immune-related adverse events (irAEs). Treatment of various malignancies, including HNSCC, with ICIs may result in the appearance of oral irAEs. In the oral cavity, irAEs such as Sicca syndrome, oral lichenoid reaction (OLR), and pemphigoid occur. It is necessary to elucidate the pathogenic mechanisms of these intractable diseases. Early diagnosis and appropriate approaches to irAE are needed for efficient treatment of advanced HNSCC by ICIs.

\begin{abstract}
Conventional chemotherapy and targeted therapies have limited efficacy against advanced head and neck squamous cell carcinoma (HNSCC). The immune checkpoint inhibitors (ICIs) such as antibodies against CTLA-4, PD-1, and PD-L1 interrupt the co-inhibitory pathway of T cells and enhance the ability of $\mathrm{CD}^{+} \mathrm{T}$ cells to destroy tumors. Even in advanced HNSCC patients with recurrent diseases and distant metastasis, ICI therapy shows efficiency and become an effective alternative to conventional chemotherapy. However, as this therapy releases the immune tolerance state, cytotoxic $\mathrm{CD}^{+} \mathrm{T}$ cells can also attack organs and tissues expressing self-antigens that crossreact with tumor antigens and induce immune-related adverse events (irAEs). When patients with HNSCC are treated with ICIs, autoimmune diseases occur in multiple organs including the skin, digestive tract, endocrine system, liver, and respiratory tract. Treatment of various malignancies, including HNSCC, with ICIs may result in the appearance of oral irAEs. In the oral cavity, an oral lichenoid reaction (OLR) and pemphigoid develop. Sicca syndrome also occurs in association with ICIs, affecting the salivary glands to induce xerostomia. It is necessary to elucidate the pathogenic mechanisms of these intractable diseases that are not seen with conventional therapy. Early diagnosis and appropriate approaches to irAEs are needed for efficient treatment of advanced HNSCC by ICIs.
\end{abstract}

Keywords: oral cavity; head and neck squamous cell carcinoma; immune checkpoint inhibitor; immune-related adverse event; cellular and humoral tumor immunity; Sicca syndrome; oral lichenoid reaction; pemphigoid

\section{Introduction}

A notable advance in the treatment of head and neck squamous cell carcinoma (HNSCC) in recent years has been the development of immunotherapy with immune checkpoint inhibitors (ICIs) using anti-CTLA-4, anti-PD-1, and anti-PD-L1 antibodies. Nivolumab and pembrolizumab are FDA-approved anti-PD-1 antibodies against HNSCC [1]. In resectable oral squamous cell carcinoma in HNSCC, radical resection and reconstructive surgery are usually performed, although radical cure by heavy ion radiotherapy has been 
also attempted [2-5]. If risk factors for recurrence are confirmed after surgery, additional chemoradiotherapy is given [6]. However, even with these treatments, recurrence occurs in $30-50 \%$ of cases [6-8]. For patients with recurrent and distant metastasis, cisplatin-based chemotherapy and/or the anti-EGFR antibody cetuximab is often used [9-11]. It is difficult to obtain a sufficient therapeutic effect in advanced stages by these conventional therapies. Moreover, re-irradiation for recurrent lesions is prone to causing serious dysfunction in eating and swallowing [12].

The activity of cytotoxic $\mathrm{CD}^{+} \mathrm{T}$ cells that recognize tumor antigens and attack tumor cells is regulated by co-stimulatory and co-inhibitory signals, in which CTLA-4-CD80/86 and PD-1-PD-L1 interactions form co-inhibitory pathways [13]. As anti-CTLA-4, anti-PD-1, and anti-PD-L1 antibodies interrupt these co-inhibitory signal pathways and restore the function of cytotoxic $\mathrm{CD}^{+} \mathrm{T}$ cells, these antibodies have been used to treat many chemoresistant cancers. The ICIs improve the outcomes of patients with malignancies including melanoma, lung cancer, and head and neck cancer, and the range of indications is further expanding [14-16]. In HNSCC, the effects of ICIs have been investigated for patients with recurrent disease and/or distant metastasis, showing resistance to cisplatin-based chemotherapy. The treatment response was found to be higher than that of chemotherapy and durable, leading to improved patient survival [17-22]. Therefore, ICI therapy is recognized as a promising treatment method for advanced HNSCC patients. In fact, the NCCN Head and Neck Cancer Guidelines recommend ICI alone or in combination with chemotherapy for recurrent, distant metastatic, and cisplatin-refractory patients [23].

The problem with this ICI therapy is that it is associated with adverse events. Whereas conventional chemotherapy/radiotherapy for HNSCC induces treatment-related adverse events mainly due to its ability to induce cell death, the ICIs reduce immune tolerance and induce immune-related adverse events (irAEs) [24]. The time of onset and healing process are different from those by conventional chemotherapy. Although ICI-induced irAEs appear in all organs throughout the body, the skin, endocrine organs, digestive tract, liver, and respiratory organs are often affected [25]. In the oral cavity, there are many autoimmune diseases including Sjogren syndrome, rheumatoid arthritis of the temporomandibular joint, systemic lupus erythematosus (SLE), systemic sclerosis, Bechet's disease, pemphigus vulgaris, pemphigoid, and oral lichen planus (OLP) [26,27]. Treatment of various malignancies, including HNSCC, with ICIs may result in the appearance of oral irAEs, but not all autoimmune diseases have been reported in patients treated with ICIs. Updating the knowledge of ICI-induced oral irAEs is essential for surgical oncologists and medical oncologists treating HNSCC and oral healthcare professionals treating oral disorders. In this article, we review the involvement of CTLA-4 and PD-1/PD-1 in tumor immunity, the mechanism by which anti-CTLA-4, anti-PD-1, and anti-PD-L1 antibodies exhibit anti-tumor effects and induce irAEs, the types of irAEs in ICI-treated HNSCC patients, and ICI-induced Sicca syndrome, oral lichenoid reaction (OLR), and oral pemphigoid lesions.

\section{Mechanisms by Which ICIs Exert Antitumor Activity and Induce irAEs}

\subsection{Involvement of CTLA-4 and PD-1/PD-L1 in Cellular and Humoral Tumor Immunity}

The $\mathrm{CD}^{+} \mathrm{T}$ cell is the main component of cell-mediated immunity against cancer. For activation of antitumor $\mathrm{CD}^{+} \mathrm{T}$ cells, tumor antigen needs to be presented by antigenpresenting cell (APC) such as dendritic cell (DC) and recognized by the $\mathrm{T}$ cell receptor (TCR) of $\mathrm{CD}^{+} \mathrm{T}$ cells. In addition, co-stimulatory signals are required for $\mathrm{T}$ cell activation. The co-stimulatory and co-inhibitory signals of T cells are mediated by the ligand-receptor pairs on the cell membrane [28]. The ligand-receptor pairs such as CD80/86-CD28, CD40LCD40, and ICOSL-ICOS promote co-stimulatory signals between DC and T cells. The pairs of co-inhibitory molecules include CD80/86-CTLA-4, PD-L1/2-PD-1, BTLA-HVEM, MHCIILAG-3, CD155/CD112/CD113-TIGIT, and galectin-9/phosphatidylserine-TIM-3 [13]. Current ICI therapy is mainly designed to suppress the action of co-inhibitory molecules to restore the anti-tumor capability of T cells. 
When tumor antigens are released into the tumor microenvironment from dying tumor cells, antigen-presenting cells (APCs) such as DCs take them up by endocytosis and migrate to local lymph nodes. In endosomes of DCs, protein antigens are processed to peptide antigens and presented on the cell surface with HMC Class II, and recognized by $\mathrm{CD}^{+}$helper T cells. In contrast, tumor antigens synthesized inside cells are decomposed into peptide fragments by proteasomes, transported into the endoplasmic reticulum by the protein transporter (TAP), binding with MHC class I molecules, and are presented on the cell surface via the Golgi apparatus to be recognized by TCR of CD8 ${ }^{+} \mathrm{T}$ cells $[24,28]$. However, even when tumor antigens are taken up by DC from the outside, they can be degraded by the proteasomes, bind to MHC class I molecules, and cross-presented on the cell surface to be recognized by CD8 ${ }^{+} \mathrm{T}$ cells. In the lymph node, naive $\mathrm{CD}^{+} \mathrm{T}$ cells that receive tumor antigens must be activated by the co-stimulatory signal through binding CD80/86 of DC cells to CD28 of T cells to become cytotoxic CD8 ${ }^{+}$T cells. Naive CD4 ${ }^{+}$T cells that receive tumor antigens through the MHC class II pathway and co-stimulatory signals from DCs differentiate into T helper 1 (Th1) cells, T helper 2 (Th2) cells, T helper 17 (Th17) cells or regulatory $\mathrm{T}$ (Treg) cells with the use of corresponding cytokines required for each $\mathrm{CD}^{+} \mathrm{T}$ cell subtype $[29,30]$. Activated $\mathrm{CD}^{+} \mathrm{T}$ cells will express the co-inhibitory molecule CTLA-4 that can bind to CD80/86 of DCs more efficiently than CD28 and suppresses the $\mathrm{T}$ cell activity. This prevents excess activation of $\mathrm{CD}^{+} \mathrm{T}$ cells through $\mathrm{DC}$ stimulating signals [31]. After activation, $\mathrm{CD}^{+} \mathrm{T}$ cells move to a peripheral tumor site and recognize tumor peptide antigens presented via MHC class I and exert antitumor activity. However, if tumor cells express the co-inhibitory molecule PD-L1, PD-1 on T cells bind to PD-L1 of tumor cells and the cytotoxicity of $\mathrm{CD}^{+} \mathrm{T}$ cells will be reduced (Figure 1A). Treg cells, which constitutively express CTLA-4, suppress $\mathrm{CD}^{+} \mathrm{T}$ cells and CD4 ${ }^{+}$helper cells by inhibiting DC maturation, consuming IL-2 by their IL-2R, and producing the inhibitory cytokines TGF- $\beta$, IL-10, and IL-35 [32].

The germinal center (GC) plays an important role in the proliferation and differentiation of B cells. B cell activation usually requires signals from B cell receptors (BCR), B cell co-receptors, and CD4 ${ }^{+}$helper T cells [33]. As an APC, B cells detect protein antigens suitable for them using a BCR with a cell membrane-bound immunoglobulin (Ig). Thereafter, tumor antigens are incorporated inside cells, processed to peptide antigens, and then presented via HMC class II to T follicular helper (Tfh) cells in GC. Tfh and GC B cells are physically connected by ligand-receptor pairs such as CD80/86-CD28, CD40L-CD40, ICOS-ICOSL, and PD-L1-PD-1. Co-stimulatory/co-inhibitory signals are transmitted through these paired molecules [34,35]. When GC B cells meet antigen-specific Tfh cells, they activate each other [36,37]. After stimulation, GC B cells differentiate into plasma cells to produce secretory immunoglobulin as an antibody (Figure 1B) and also differentiate into memory B cells [33,37] (Figure 1B). IL-21 secreted from Tfh cells binds IL-21R, a co-receptor of GC B cells. IL-21R signaling can induce Bcl-6 expression and promote B-cell proliferation [38]. In contrast, $\mathrm{T}$ follicular regulatory ( $\mathrm{Tfr}$ ) cells suppress Tfh and B cells through CTLA-4 in GC. Production of inhibitory cytokines such as IL-10 and TGF- $\beta$ may be another way by which Tfr cells inhibit B cell responses [39].

In melanoma patients, induction of tumor immunity is known to cause autoimmune disease [40]. Indeed, vitiligo was reported to occur as an autoimmune response in patients whose melanoma showed spontaneous remission. It is considered that this is because cytotoxic $\mathrm{CD}^{+} \mathrm{T}$ cells recognize both normal melanocytes, the target in this autoimmune disease, as well as melanoma cells and destroy these cells (Figure 1A). In animal experiments, white hair grew in black-haired mice after treatment with an antibody against tyrosinase and related proteins (TRP-1), a melanogenic enzyme. This antibody also blocked the growth of transplanted melanoma in mice, suggesting that melanocyte TRP-1 acts as tumor antigen [41]. Autoantibodies that recognize tyrosinase, TRP-1, and TRP-2, have been detected in melanoma patients with vitiligo [42]. 
A
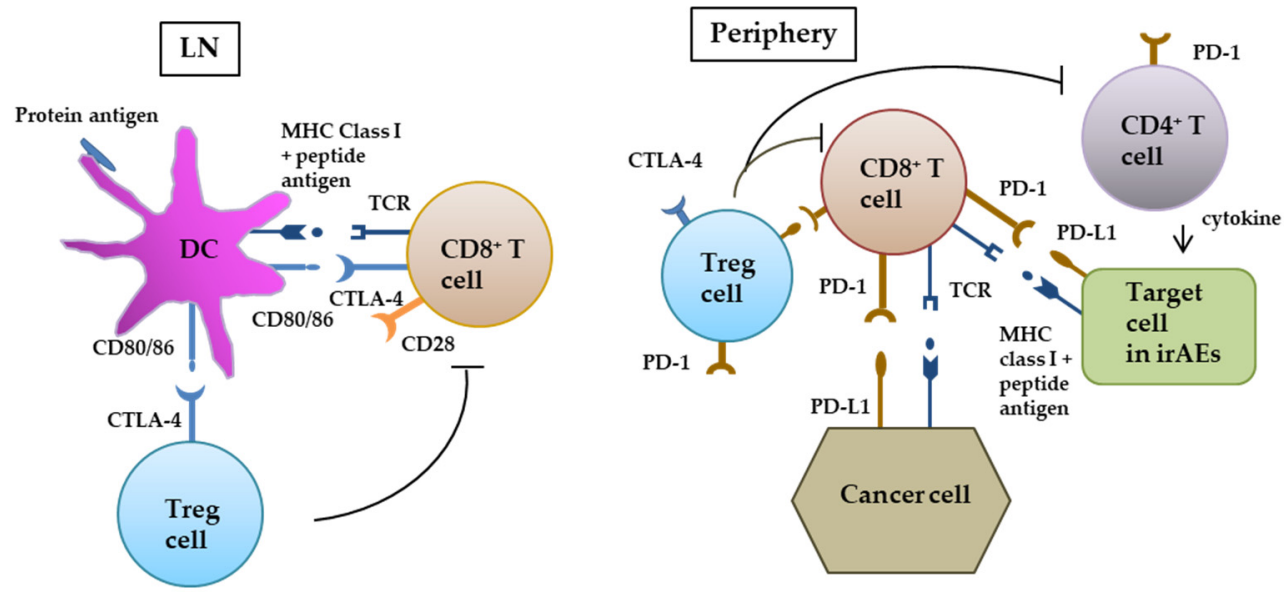

B



Figure 1. CTLA-4 and PD-1/PD-L1 in cellular (A) and humoral (B) tumor immunity. (A) In the CD8 ${ }^{+}$ $\mathrm{T}$ cell-based pathway, when tumor antigens are released into the tumor microenvironment from dying tumor cells, DCs take up the protein antigens and decomposes them to peptide antigens. In regional lymph nodes, the peptide antigens are cross-presented via MHC class I on the cell surface and recognized by the TCR of $\mathrm{CD}^{+} \mathrm{T}$ cells. In addition, the co-stimulatory binding of CD80/86 of DCs with CD28 of $\mathrm{T}$ cells is required for naïve $\mathrm{CD} 8^{+} \mathrm{T}$ cells to differentiate into cytotoxic CD8 ${ }^{+} \mathrm{T}$ cells. Activated $\mathrm{CD} 8^{+} \mathrm{T}$ cells express the co-inhibitory molecule CTLA- 4 to prevent excess activation of $\mathrm{CD}^{+} \mathrm{T}$ cells. $\mathrm{CD} 8^{+} \mathrm{T}$ cells move to a peripheral tumor site and recognize tumor peptide antigens presented via MHC class I and exert antitumor activity. However, PD-I on $\mathrm{CD}^{+} \mathrm{T}$ cells binds PD-L1 on tumor cells and suppresses the activity of CD8 ${ }^{+} \mathrm{T}$ cells. Treg cells locally suppress the activity of $\mathrm{CD}^{+} \mathrm{T}$ cells and $\mathrm{CD} 4^{+}$helper cells. (B) The germinal center (GC) plays an important role in the proliferation and differentiation of $\mathrm{B}$ cells. Tfh cells physically bind to GC B cells by co-stimulatory/co-inhibitory pairs such as CD28-CD80/86, CD40L-CD40, ICOS-ICOSL, PD-1, and PD-L1. BCR expressed on B cells detects the protein antigens, and take them into the cells. Peptide antigens processed in B cells are then presented via MHC class II and recognized by Tfh cells. Interaction between Th and B cells promotes the differentiation of GC B cells into plasma cells and memory B cells. Tfr cells suppress Tfh and B cells. LN, lymph node; Treg, regulatory T; TCR, T cell receptor; irAEs, immune-related adverse events; GC, germinal center; Tfh, $\mathrm{T}$ follicular helper; Tfr, $\mathrm{T}$ follicular regulatory; PC, plasma cell; BCR, B cell receptor.

\subsection{Anti-CTLA-4, anti-PD-1, anti-PD-L1 Antibodies as Antitumor Agents and Autoimmune Disease Inducers}

IrAEs have been reported to occur more often in patients treated with anti-CTLA-4 compared to patients treated with anti-PD-1 and anti-PD-L1 [43]. Among the ICIs currently used in HNSCC, ipilimumab against CTLA-4 and atezolizumab and durvalumab 
against PD-L1 are IgG1, while nivolumab and pembrolizumab against PD-1 are IgG4. In the case of IgG1 antibody, the Fc portion of antibody in immunocomplexes can mediate antibody-dependent cellular cytotoxicity (ADCC), antibody-dependent cellular phagocytosis (ADCP), and complement-dependent cytotoxicity (CDC) [44-46]. These actions may contribute to IgG1-mediated cytotoxicity.

When cancer patients are treated with anti-CTLA- 4 antibodies, CD8 ${ }^{+} \mathrm{T}$ cells are released from their anergy state and attack tumor cells, but at the same time, $\mathrm{CD}^{+} \mathrm{T}$ cells also attack normal cells that present cross-reactive antigens. The $\mathrm{CD}^{+} \mathrm{T}$ cell is also released from a suppressive state [47]. When peripheral blood mononuclear cells (PBMCs) from melanoma patients who received a CTLA-4 blockade, tremelimumab, were activated in vitro, there was no difference in the levels of Th17 between patients with or without antitumor effects, but a marked increase in IL-17 and Th17 cells was observed in patients with inflammatory and autoimmune responses [48]. It was also reported that Fc receptorpositive phagocytes recognized the anti-CTLA- 4 antibody conjugated to CTLA-4 on Treg and reduced the number of Treg $[49,50]$. In fact, in a mouse colorectal cancer model, antiCTLA-4 antibodies caused a rapid decrease of intratumoral Tregs, while they increased peripheral Treg cells [51]. Similarly, treatment of colorectal cancer-bearing mice with antiCTLA-4 antibodies decreased Foxp3 ${ }^{+} / \mathrm{CD}^{+}{ }^{+}$Treg cells, but increased CD4 ${ }^{+} \mathrm{T}$ and $\mathrm{CD}^{+}$ $\mathrm{T}$ cells and the expression levels of pro-inflammatory Th1/M1-related cytokines IFN- $\gamma$, IL- $1 \alpha$, IL-2, and IL-12 [52]. The effects of anti-CTLA- 4 antibody on CD8 ${ }^{+}$T, CD4 $4^{+}$T, and Treg cells may contribute to the induction of autoimmune diseases.

PD-1 plays an important role in maintaining peripheral immune tolerance. The ligand PD-L1 is constitutively expressed on B cells, T cells, macrophages, and DCs, while PD-L2 is not expressed on quiescent cells and is induced by pro-inflammatory cytokines [32]. Anti-PD-1 antibody inhibits the binding of PD-1 and PD-L1/L2 on tumor cells. As a result, cytotoxic $\mathrm{CD}^{+} \mathrm{T}$ cells exert efficient antitumor activity via Fas, granzyme $\mathrm{B}$, perforin, and IFN- $\gamma$. In fact, an increase in the levels of activated effector memory $\mathrm{T}$ cells and central memory $\mathrm{T}$ cell subsets of $\mathrm{CD}^{+}$and $\mathrm{CD}^{+} \mathrm{T}$ cells, and activated Th1 plus T-helper follicular 1 cells was observed in melanoma patients treated with anti-PD-1 antibodies [53]. The relationship between PD-1 and Treg cells was investigated in animal models where anti-PD-1 antibody suppressed tumor growth and prolonged survival of osteosarcoma cancer-bearing mice. Anti-PD-1 antibodies were found to decrease intratumoral Treg cells, while they increased tumor-infiltrating immune cells [54]. In a chronic inflammation model, linking PD- 1 on Treg cells to PD-L1 on $\mathrm{CD}^{+} \mathrm{T}$ cells suppressed the activity of $\mathrm{CD} 8^{+} \mathrm{T}$ cells, which was abolished by reducing PD-1 expression of Treg cells [55]. In contrast, Toor et al. reported that pembrolizumab efficiently blocked PD-1 expression on peripheral blood cells of healthy subjects and breast cancer patients in vitro, but that it did not affect the expression of Treg-related markers or function. The pembrolizumab-mediated blockade was observed in only $\mathrm{CD} 4{ }^{+} \mathrm{CD} 25^{+}$non-Treg cells [56]. Kamada-T et al. [57] reported patients with hyperprogressive disease in whom anti-PD-1 had no antitumor effects but rather caused rapid tumor growth with the proliferation of PD-1 ${ }^{+}$Treg, suggesting that the anti-PD1 antibody can induce a strong immunosuppressive status. In patients who receive anti-PD-1 antibodies and develop the hyperprogressive disease, an attempt is made to suppress Treg cells by adding anti-CTLA-4 antibodies [58].

A characteristic of autoimmune diseases is the production of autoantibodies, where B cells play a major role [59]. Autoantibodies against thyroid antigens are detectable in ICIrelated thyroiditis and hypothyroidism [60]. Autoantibodies against islet cell antigens and glutamic acid decardoxylase-65 were observed in patients who developed diabetes after ICI treatment $[61,62]$. Pemphigoid observed in ICI-treated patients is associated with the production of autoantibodies against basement membrane zone antigens $[63,64]$. It has been shown that a blockade of PD-1/PD-L1 signal can either enhance or suppress the humoral immune response [37]. In a mouse model, blockage of the PD-1 blockade was found to augment humeral immunity through the accumulation of GC CD4 ${ }^{+} \mathrm{T}$ cells expressing ICOS and differentiation of B cells [33]. Anti-PD-1 antibody may exert its enhancing 
effect on B cells through Tfh and Tfr, but it can also directly act on PD-1 expressed on B cells [37]. Das et al. [65] reported that although anti-CTLA-4 and anti-PD-1 antibodies had no apparent effects on B cells in advanced melanoma patients when administered individually, their combination increased in serum plasmablasts and CXCL13, a marker of GC activation. Particularly, in a subset of CD21 ${ }^{\text {low }}$ memory B cells, the combined treatment decreased the expression of PD-1, and increased the number of cells showing high IFN- $\gamma$ signals, indicating the ability of the anti-PD-1 antibody to promote humoral immunity. In contrast, B cell reactivity elicited by protein immunization was shown to be reduced in mice that lack PD-1 and PD-1 ligands [33,66,67]. The anti-PD-1 antibodies may weaken the binding integrity of Tfh cells with GC B cells through CD40-CD40L and ICOS-ICOSL and prevent the activation of B cells (Figure 1B). Willsmore et al. [59] stated that although $B$ cells express PD-1 and PD-L1, these are not recognized as primary targets for anti-PD-1 antibody therapy.

ICIs treatment causes relapse in patients with autoimmune disease [68]. As antigen epitopes are shared with the tumor and target organ of autoimmune diseases, ICIs will lower the threshold for antigen-specific T cell activation and cause irAEs [69]. Autoantibodies were reported to become detectable in $19.2 \%$ of melanoma patients after treatment with anti-CTLA-4 antibody [70]. Relapse of autoimmune disease after ICI treatment was also observed in $38 \%$ of melanoma patients [71]. This suggests the importance of pre- or subclinical autoimmune disease in the onset of irAEs but also indicates the role of other factors in the development of ICI-induced irAEs. The direct effect of ICIs on target cells has also been reported. A typical event is hypophysitis. This is because CTLA-4 is highly expressed in the pituitary gland, so anti-CTLA- 4 antibodies directly bind and injure the gland through ADCP and/or CDC to induce hypophysitis [44]. PD-L1 is expressed not only in lymphoid tissues but also in non-lymphoid tissues such as vascular endothelial cells, the thyroid, muscle, liver, placenta, mesenchymal cells, and the pancreas to maintain peripheral immune tolerance [72-75]. Anti-PD-L1 antibodies may bind directly to cells of these tissues/organs and exhibit cytotoxicity via Fc receptors.

Bacterial species such as Bacteroides, Clostridium, and Faecalibacterium were shown to expand Treg and produce anti-inflammatory cytokines. Recently, the relationship between the gut microbiota and irAEs has been investigated [76,77]. Dubin et al. [76] found that species belonging to the Bacteroidetes phylum conferred resistance to colitis that developed after anti-CTLA-4 antibody therapy, suggesting that expansion of these bacteria helps to prevent the development of ICI-induced colitis. The microbiota plays an important role in the endogenous synthesis of water-soluble B vitamins. A reduced capacity for microbemediated production of $B$ vitamins and polyamine transport may lower the threshold for the onset of immune-mediated colitis. The group 3 innate lymphoid cells (ILC3s) are the major innate lymphoid cell type involved in the immunopathology of ICI-induced colitis. Lactobacillus reuteri (L.reuteri) administration markedly decreased the mucosal numbers of ILC3s and therapeutically prevented colitis in the ICI-treated mice. This suggests that L. reuteri affects the immunopathology of ICI-associated colitis primarily by altering the local number of ILC3s. [78]. Oral administration of Bacteroides fragilis, Bacterodes thetaiotaomicron, and Burkholderia cepacia was found to restore the antitumor effects of anti-CTLA-4 antibody in MCA205 sarcoma-bearing mice treated with a broad-spectrum antibacterial cocktail. These bacteria enhanced antitumor immunity by inducing the Th1 immune response in regional lymph nodes and promoting DC maturation [79]. Some oral bacteria migrate to the intestinal tract. Therefore, oral bacteria may be useful to alleviate the colitis caused by ICIs [80].

\section{ICI-Induced irAEs in Advanced HNSCC Patients}

In HNSCC, PD-L1 is highly expressed in a variety of immune and non-immune cells, including tumor cells and cancer-associated fibroblasts [81]. As advanced HNSCC patients are frequently treated with anti-PD-1 antibodies, most reported irAEs are related to nivolumab and pembrolizumab [17-22,82-84] (Table 1). A study by Ferris et al. com- 
pared 361 HNSCC patients treated with nivolumab to patients treated with standard chemotherapy including methotrexate, docetaxel, or cetuximab. Mean survival was 7.5 and 5.1 months, respectively, overall survival was significantly increased in the nivolumab group and 1-year survival was 36 and 16.6\%, respectively, improving by $19 \%$. The overall incidence of irAEs induced by nivolumab was 58.9\% (139/236) and that of grade 3-4 was $13.1 \%(31 / 236)$, while the incidences of overall and high-grade AEs due to standard chemotherapy were $77.5 \%(86 / 111)$ and $35.1 \%(39 / 111)$, respectively; the incidence of irAE by nivolumab is low compared with conventional chemotherapy. The most common ICI-induced irAEs were gastrointestinal disorders that occurred in 61 (25.8\%) patients, of which $20(8.5 \%)$ involved nausea, $17(7.2 \%)$ appetite decrease, $16(6.8 \%)$ diarrhea, and 8 (3.4\%) vomiting. Dermatological irAEs occurred in $42(18 \%)$ patients, of which $18(7.6 \%)$ involved rash, $17(7.2 \%)$ pruritus, and $7(3.0 \%)$ dry skin. As a systemic event, fatigue was observed in $33(14.0 \%)$ patients (Table 1). Matsumo et al. [22] reported endocrine disease as an irAE by nivolumab in 14 (26.4\%) of 108 patients. Bauml et al. [19] analyzed patients treated with pembrolizumab, and reported that the overall incidence of irAE was $63.7 \%$ $(109 / 171)$ and that of grade $3-4$ irAEs was 15.2\% (26/171). Of all irAEs, 30 (17.5\%) involved gastrointestinal disorders, 21 (12.3\%) dermatologic disease, 27 (15.8\%) liver dysfunction, $30(17.5 \%)$ general disorders, and 16 (9.3\%) endocrine diseases. The frequency of serious irAEs was low. Oral mucosal diseases were reported by Mehra et al. [83] in 4 (2.1\%) of 192 patients and by Burtness et al. [21] in 9 (3\%) of 300 patients without serious irAEs. 
Table 1. Immune checkpoint inhibitor-induced adverse events in studies of HNSCC patients.

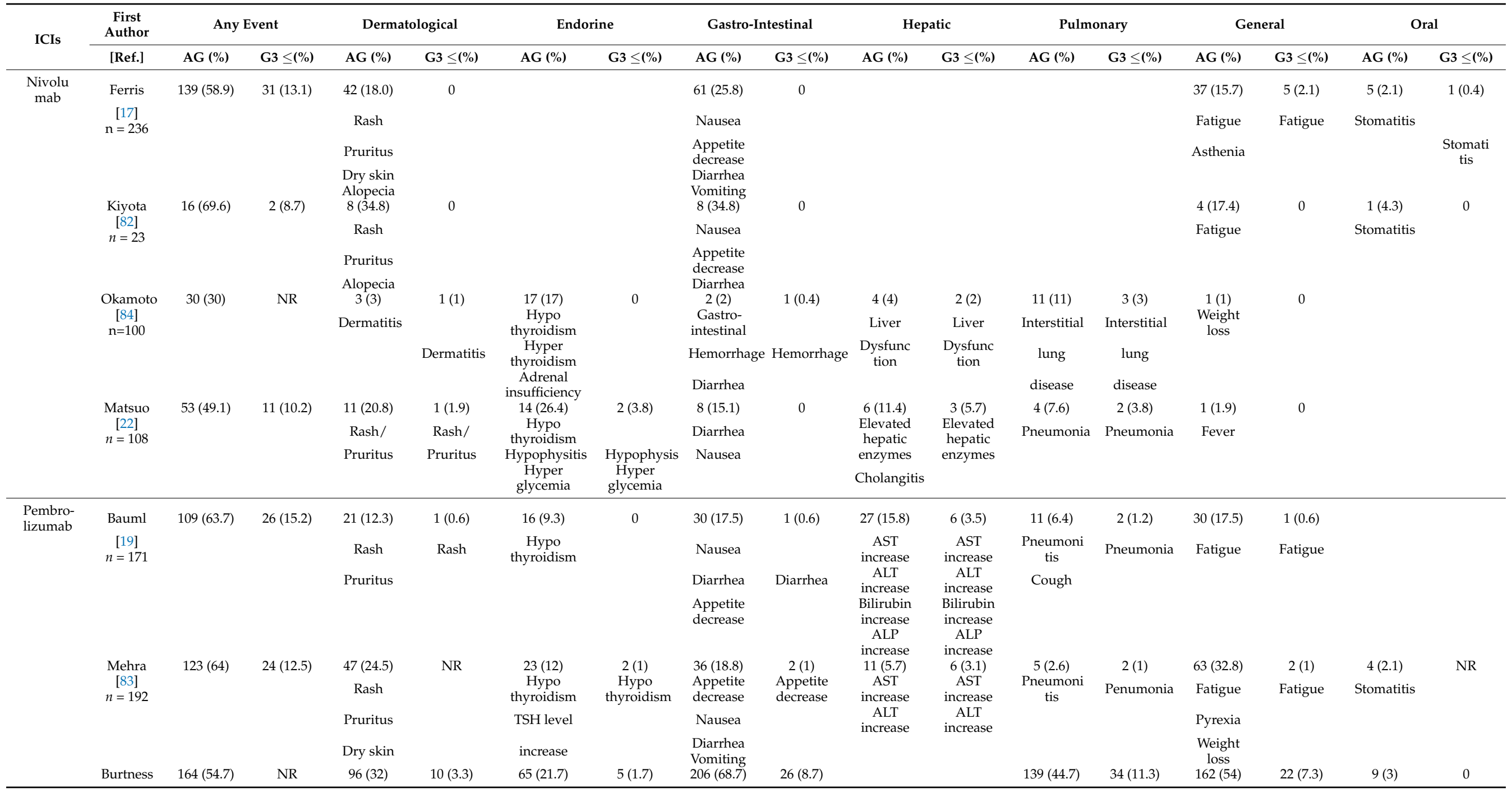


Table 1. Cont.

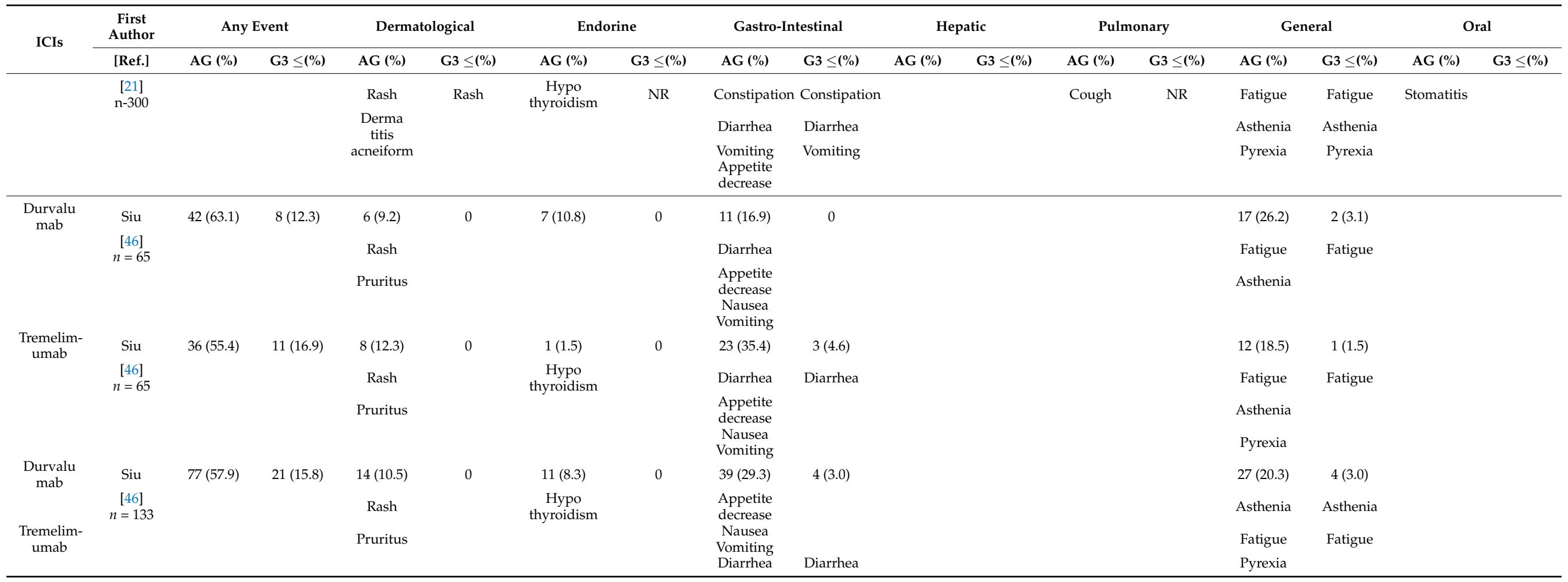

ICI, immune checkpoint inhibitor; AG, any grade; G, grade; NR, not reported. 
Compared with HNSCC, ICI treatment for melanoma (CheckMate 037) was started in advance, in which the overall frequency of nivolumab-induced irAEs was 59\% $(157 / 268)$ and that of grade 3-4 was 9\% (22/268) (Checkmate 037 2015) [16]. In another study of 278 melanoma patients, pembrolizumab (Check Mate 006) induced irAEs in 221 (79.5\%) patients and grade 3-5 occurred in 37 (13.3\%) patients (Keynote 006 2015) [15]. In 418 lung cancer patients treated with nivolumab, (Checkmate 057), irAEs occurred in 283 (68\%) patients and grade $3-4$ occurred in $44(10 \%)$ patients [85]. The frequencies of overall irAEs in ICI-treated HNSCC patients ranged from 30 to $69.6 \%$ (Table 1 ). Therefore, there was no apparent difference in the incidences of nivolumab-induced irAE among patients with melanoma, lung cancer, and HNSCC. The major organs involved in these malignancies are the digestive tracts and skin.

Recently, the anti-PD-L1 antibodies durvalumab and atezolizumab have been used for the treatment of HNSCC patients [46,86]. Sui et al. [46] treated advanced HNSCC patients with the anti-PD-L1 antibody durvalumab and/or anti-CTLA-4 antibody tremelimumab. The overall irAE incidences in patients treated with durvalumab, tremelimumab, and their combination were $63.1 \%(41 / 65), 55.4 \%(36 / 65)$, and $57.9 \%(77 / 133)$, respectively, and those of grade 3-4 irAEs were 12.3\% (8/65), 16.9\% (11/65), and 15.8\% (21/133), respectively. These antibodies against PD-L1 induced irAEs in HNSCC patients at frequencies similar to nivolumab and pembrolizumab.

\section{Induction of Sicca syndrome by ICIs}

Primary Sjogren syndrome (pSS) is a systemic autoimmune disease in which symptoms appear in many exocrine organs during the course of the disease with diverse clinical features, but in principle salivary and lacrimal glands are affected and dry mouth and dry eye occur. Many factors, including environmental and genetic factors, play roles in the development of pSS $[87,88]$. In histology of the affected exocrine glands, there is periductal accumulation of mononuclear cells composed of mainly $\mathrm{CD}^{+} \mathrm{T}$ and B cells. GC formation, hypergamma globulinemia, and the production of autoantibodies SS-A and SS-B reflect the excessive activity of B cells. Among the $\mathrm{CD}^{+} \mathrm{T}$ cells that accumulate periductally, Th1, Tfh, and Th17 are implicated to play important roles in the development of pSS [89-91].

There are case reports of Sjogren syndrome/Sicca syndrome that occurred in association with ICI treatment for various malignancies with similar clinical features as pSS that have been published. According to the reports, dry mouth and dry eyes were observed in $98(5.3 \%)$ of 1832 patients. The frequency of Sicca syndrome observed with the combination of anti-CTLA-4 antibody and anti-PD-1 antibody was $9.4 \%$, and that with anti-CTLA-4 alone was 1.4\% [92]. Le Burel et al. [93] reported that out of 908 patients who received anti-PD-1/PD-L1 treatment, the estimated prevalence of Sjogren syndrome was $0.3 \%$, while it increased to $2.5 \%$ among patients treated with the combined use of ICIs. Ramos-Casals et al. [92] summarized the characteristics of their 26 patients who developed ICI-induced Sicca/Sjogren syndrome. The characteristics of the reported 76 patients, including sex distribution, underlying malignancies, time to onset, prevalence of pSS-associated autoantibodies, other irAEs, and degree of improvement of irAEs, were analyzed [92-100] (Figure 2). pSS has been shown to occur predominantly in women, with $95 \%$ of patients reported to be female [92], but among the 76 patients with Sicca syndrome caused by ICIs, $48(63 \%)$ patients were male and $28(37 \%)$ patients were female (Figure $2 \mathrm{~A})$. In the study by Ramos-Casals et al. [92], the male-female ratio was 1:1. Therefore, Sicca syndrome due to ICIs is not confined to women. The primary malignancies were melanoma, lung cancer, and renal cancer (Figure 2B). Melanoma accounted for $38 \%$ of the total. Oral cancer was limited to two cases. 
A

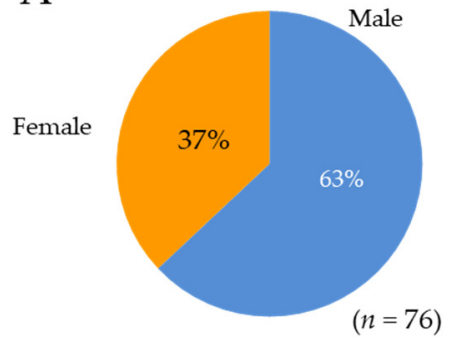

C
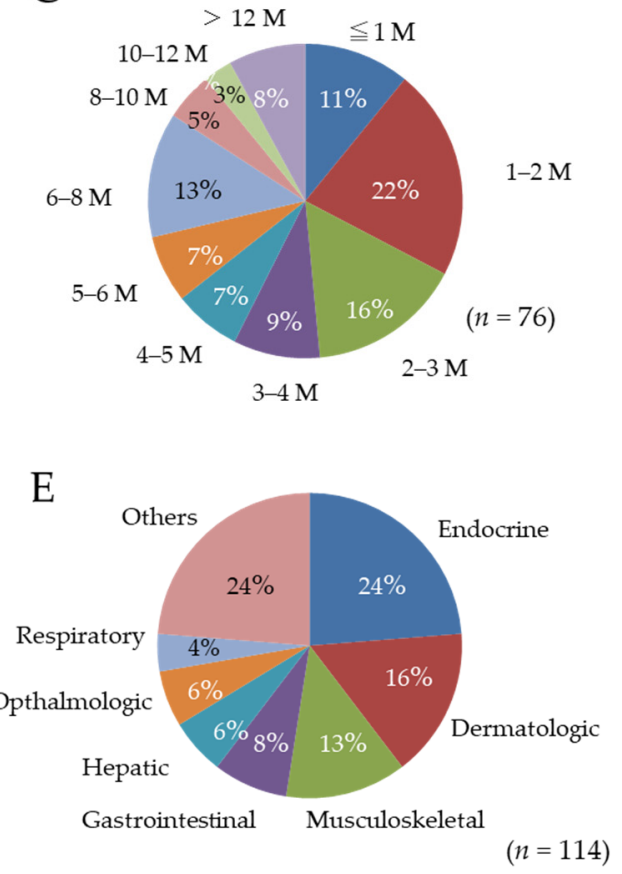

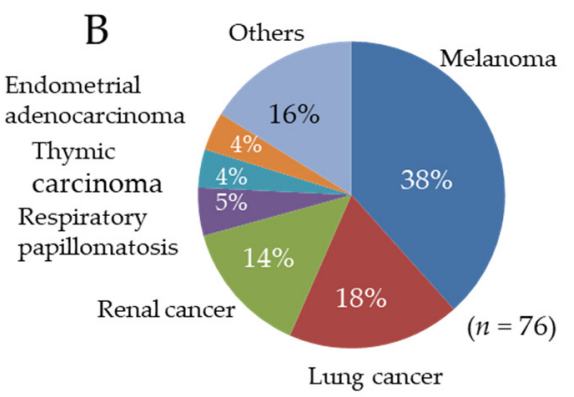

$\mathrm{D}$

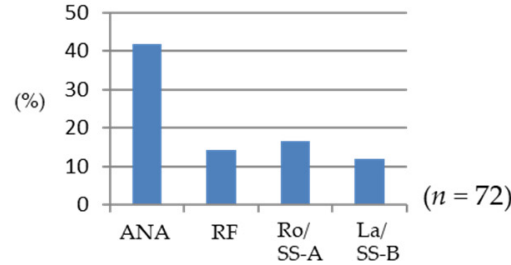

No

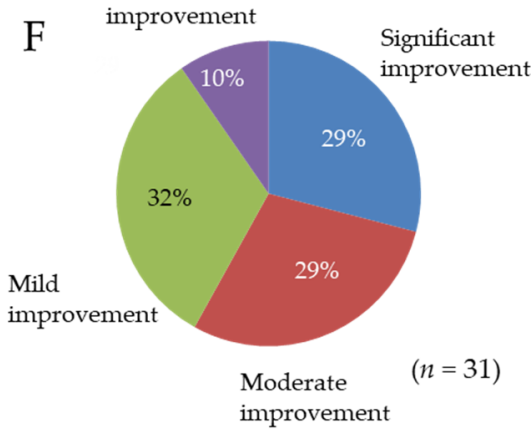

Figure 2. Characteristics of 76 previously reported patients with ICI-induced Sicca syndrome. (A) Sex. (B) Types of underlying malignancies. (C) Time to onset, months. (D) Prevalence of Sicca syndromerelated serum autoantibodies. (E) Other irAEs. (F) Degree of improvement of irAEs.

Of the 52 patients in whom the names of antibodies were clarified, nivolumab, pembrolizumab, and their combination were administered to 18 (34.6\%), $10(19.2 \%)$, and 10 $(19.2 \%)$ patients, respectively. After the start of ICI treatment, Sicca syndrome occurred at a constant rate every month, with $71 \%$ by half a year and $92 \%$ by 12 months (Figure $2 \mathrm{C}$ ). A total of 37/76 (47\%) patients developed Sicca syndrome by 3 months. In the case of pSS, $70 \%$ of immune cells that infiltrated into the salivary gland were shown to be T cells, of which $50 \%$ were $\mathrm{CD} 4^{+} \mathrm{T}$ cells and $20 \%$ was $\mathrm{CD} 8^{+} \mathrm{T}$ cells; the proportion of $\mathrm{B}$ cells was $22 \%[101,102]$. In a study on ICI-induced Sicca syndrome, most infiltrating cells were T cells, with more $\mathrm{CD}^{+} \mathrm{T}$ cells than $\mathrm{CD} 8^{+} \mathrm{T}$ cells and only a few $\mathrm{CD} 20^{+} \mathrm{B}$ cells [98]. A histological study of the lower lip mucosa revealed that although aggregated $\mathrm{CD} 20^{+} \mathrm{B}$ cells and $\mathrm{CD} 3^{+}$ $\mathrm{T}$ cells were observed, $\mathrm{T}$ cells were predominant and the $\mathrm{CD} 8^{+} \mathrm{T}$ cell was more frequent than the $\mathrm{CD} 4^{+} \mathrm{T}$ cell [100]. This indicates that much lower levels of B cells infiltrate the salivary gland in ICI-induced Sicca syndrome compared with pSS. In a previous study analyzing 26 patients, there was a prevalence of SS-associated serum autoantibodies (48\% anti-nuclear antibody (ANA), 32\% rheumatoid factor (RF), 48\% SS-A, and 25\% SS-B) [92]. In 72 patients in this study, the detection rates of ANA, RF, SS-A, and SS-B were 42, 14, 17, and $12 \%$, respectively (Figure 2D). In the case of pSS, these antibodies were detectable in 79 , 48,73 , and $45 \%$, respectively. The prevalence of serum autoantibodies in ICI-induced Sicca 
syndrome is much lower in comparison with pSS. Other irAEs observed in the patients with ICI-induced Sicca syndrome include endocrine, dermatological, musculoskeletal, digestive, and liver disorders (Figure 2E).

When the symptoms of irAEs are severe, ICI administration is discontinued. Indeed, $36 / 65(55 \%)$ discontinued ICI treatment due to irAE. For the treatment of ICI-induced Sicca syndrome, systemic corticosteroid was administered. As a result, among 31 evaluable patients, significant improvement was observed in $9(29 \%)$, moderate improvement in $9(29 \%)$, mild improvement in $10(32 \%)$, and no improvement in $3(10 \%)$ patients (Figure 2F). Corticosteroids were demonstrated to be useful, but their therapeutic effects were insufficient in $12(42 \%)$ patients.

\section{Induction of Oral Mucosal Lesions by ICIs}

The frequency of skin irAEs due to anti-PD-1 antibody was relatively high, with rash at $7.2 \%$, pruritus $7.2 \%$, and dry skin at $3 \%$. When patients with HNSCC were treated with anti-PD-1 antibody, the incidence of stomatitis was $2.1 \%$ and that of grade $3-4$ disease was $0.4 \%$, which is less frequent than skin disorders caused by ICIs [17]. With conventional chemotherapy for HNSCC, $9 \%$ of patients treated with cisplatin + fluorouracil developed mouth ulcer, of which $2.7 \%$ was grade $3-4$ [17]. Therefore, the frequency of mouth ulcer caused by ICIs is also low compared with conventional chemotherapy.

OLP is a chronic inflammatory mucosal disease for which the cause of the autoimmune reaction has not been identified. It frequently occurs in women and involves the formation of reticular lesions on the buccal mucosa on both sides. Histologically, it is characterized by chronic inflammation and submucosal band-shaped T cell infiltration [103,104]. In contrast, an oral lichenoid lesion (OLL), with similar clinical and histological features to OLP, is associated with dental restorations, drugs, liver disease, hypertension, systemic diseases such as diabetes, and food and spice allergies. Therefore, OLL can be further divided into four types: amalgam restoration-associated OLL; drug-related OLL; OLL in chronic graft-versus-host disease (GVHD); and OLL unclassified [105,106]. OLL is also called OLR, lichenoid stomatitis, and lichen planus-like lesion [105]. In this review, OLP-like lesions were called OLR [107-113]. In the oral cavity, ICI-induced OLR affects the buccal mucosa, tongue, and gums and shows clinical appearances including reticular, white-lined, ulcer, erythema multiforme (EM)-like, and GVHD-like lesions. Since no obvious symptoms were observed in most white plaque and papular lesions, biopsy was not necessarily performed.

Indeed, of the 32 patients with OLR lesions reported previously, only $11(34 \%)$ underwent histological examination. Careful clinical examination is required to discover oral lesions in patients with no or mild symptoms. Of the 32 reported patients with ICIrelated OLR, 20 patients were treated with nivolumab, 8 patients with pembrolizumab, and 4 patients with atezolizumab. As the primary malignancies, 7 lung cancers, 7 melanomas, 4 renal cell carcinomas, and 4 OSCCs were included (Table 2). The onset time ranged from 1 to 23 cycles. Histological examination of ulcerative lesions revealed a total epithelial defect and subepithelial lichen planus-like lymphocyte infiltration. Eosinophil or neutrophil infiltration is not usually observed in OLP [114]. Shazib et al. [112] reported 4 cases of lichenoid mucositis with eosinophilia, suggesting that the mucosal lesion is not OLP, but has a histological characteristic of drug hypersensitivity. Immunoreactive self-antigen was not detected in these OLR lesions by the direct immunofluorescence (DIF) method.

Outside the oral cavity, skin papules, skin LPs, and pneumonia are observed as irAEs. Most patients with OLR were treated with topical application of corticosteroids. When the effect was insufficient, systemic corticosteroids were administered. All of them improved after several weeks. ICIs were discontinued in 10/18 (56\%) patients due to irAE. Shi et al. [107] found that $16 / 20(80 \%)$ of ICI-treated cancer patients had already taken drugs with a potential to induce OLR, and suggested that ICIs broke immune tolerance locally and evoked an immunological response to these drugs. On the other hand, a 43-year-old woman with follicular lymphoma was treated with rituximab and developed OLR [115]. A 68-year-old woman also developed OLR with oral pain caused by abatacept 
on treating rheumatoid arthritis [116]. Abatacept is CTLA-4-Ig that binds CD80/86 on DC and blocks the co-stimulatory signal through CD28 of T cells, which suppresses T cell-mediated inflammation of rheumatoid arthritis. These findings suggest that OLR may occur as hypersensitivity to the monoclonal antibody in these patients.

Severe oral ulcers due to ICIs have been also reported, and some extend to the pharynx [117-120]. In three patients with severe ulcers, ICI discontinuation and systemic administration of prednisolone improved the lesions. A 93-year-old patient received nivolumab for the treatment of pharyngeal cancer and developed multiple oral ulcers during the treatment, while the tumor disappeared. The ulcers were not improved by oral prednisolone or intravenous methylprednisolone, but improved by oral cyclophosphamide and colchicine gargle. This suggests that the ulcers are associated with Behcet's disease [119].

In addition, there are patients who developed oral pemphigoid lesions related to ICI treatment [63,121-128]. ICI-induced mucous membrane pemphigoid (MMP) is rare, with only two patients being reported [63,125]. MMP patients have autoantibodies to the basement membrane zone antigens, and the main target of autoantibodies is the hemoidesmosomal protein BP180. MMP lesions caused by ICIs appeared on the gingiva, tongue, and buccal mucosa without other systemic lesions. Direct immunofluorescence (DIF) was positive. The MMP lesions improved by discontinuation of ICIs and administration of doxycycline. Nine patients with bullous pemphigoid (BP) with oral lesions have been reported (Table 2). Zumelzu et al. [63] examined the characteristics of 29 patients with ICI-induced BP, of whom $6(21 \%)$ patients had oral lesions. Sadik et al. [127] reported oral involvement in 2/12 (17\%) BP patients. Oral BP lesions appear on the buccal mucosa, palate, and tongue. The major self-antigens are BP180 and BP230 of the dermal-epidermal junction [128]. BP180 is known to be expressed on the cell surface of melanoma, non-small cell lung cancer, and urothelial epithelium. Administration of anti-PD-1/PD-L1 antibody will promote immune cross-reactivity against BP180 on tumor cells and on the basement membrane of the skin, leading to the development of BP [129]. Because a high level of BP180 expression in NSCLC tissue is correlated with a better therapeutic effect of ICIs, serum BP180 is a potential marker to infer autoantibody production and responsiveness to ICI therapy [64]. Yatim et al. [130] reported a patient with paraneoplastic pemphigus and detected Dsg1 and Dsg3 by serological examination. Discontinuation of ICIs, topical dexamethasone (DEX), oral prednisolone, and doxycycline improved the lesions of BP and paraneoplastic pemphigus. 
Table 2. Immune checkpoint inhibitor-induced adverse events in the oral cavity.

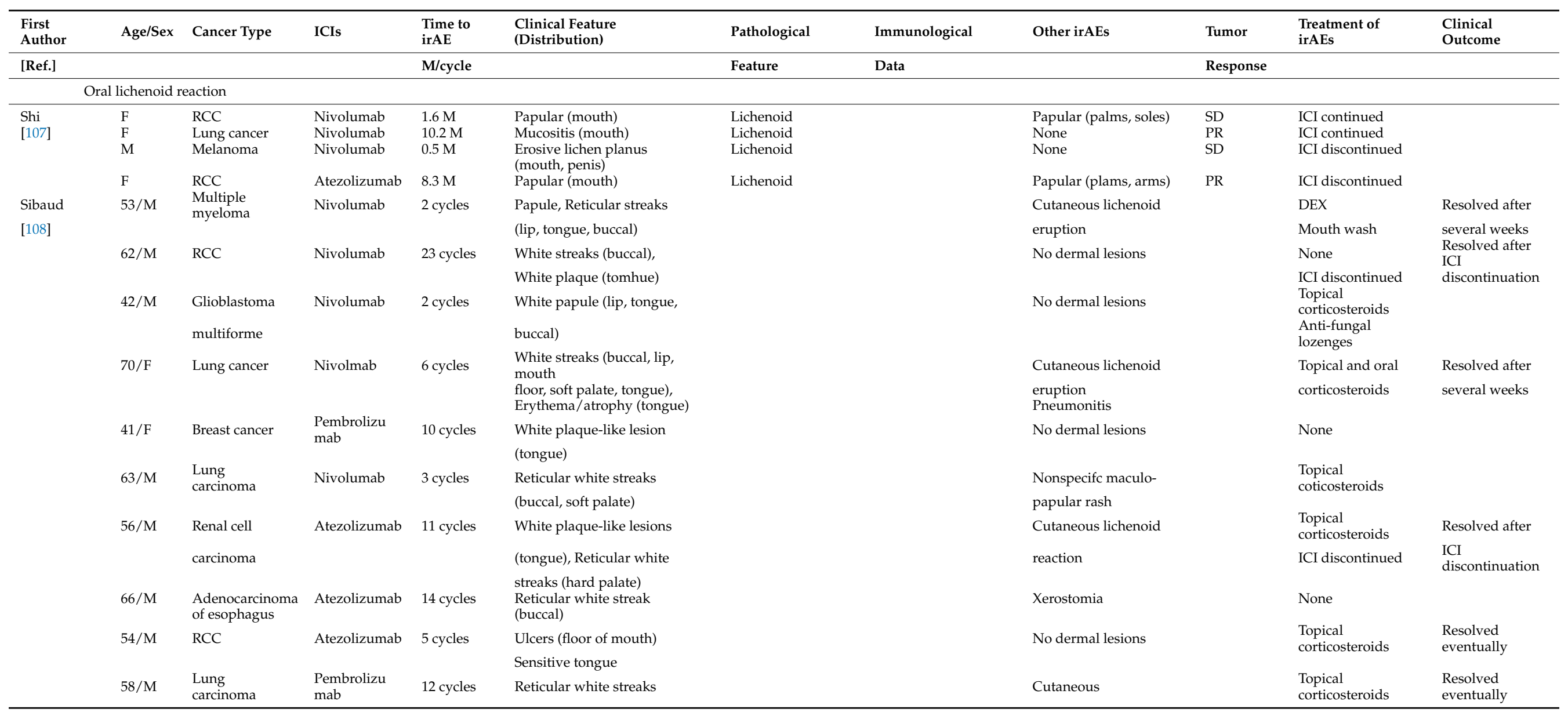


Table 2. Cont.

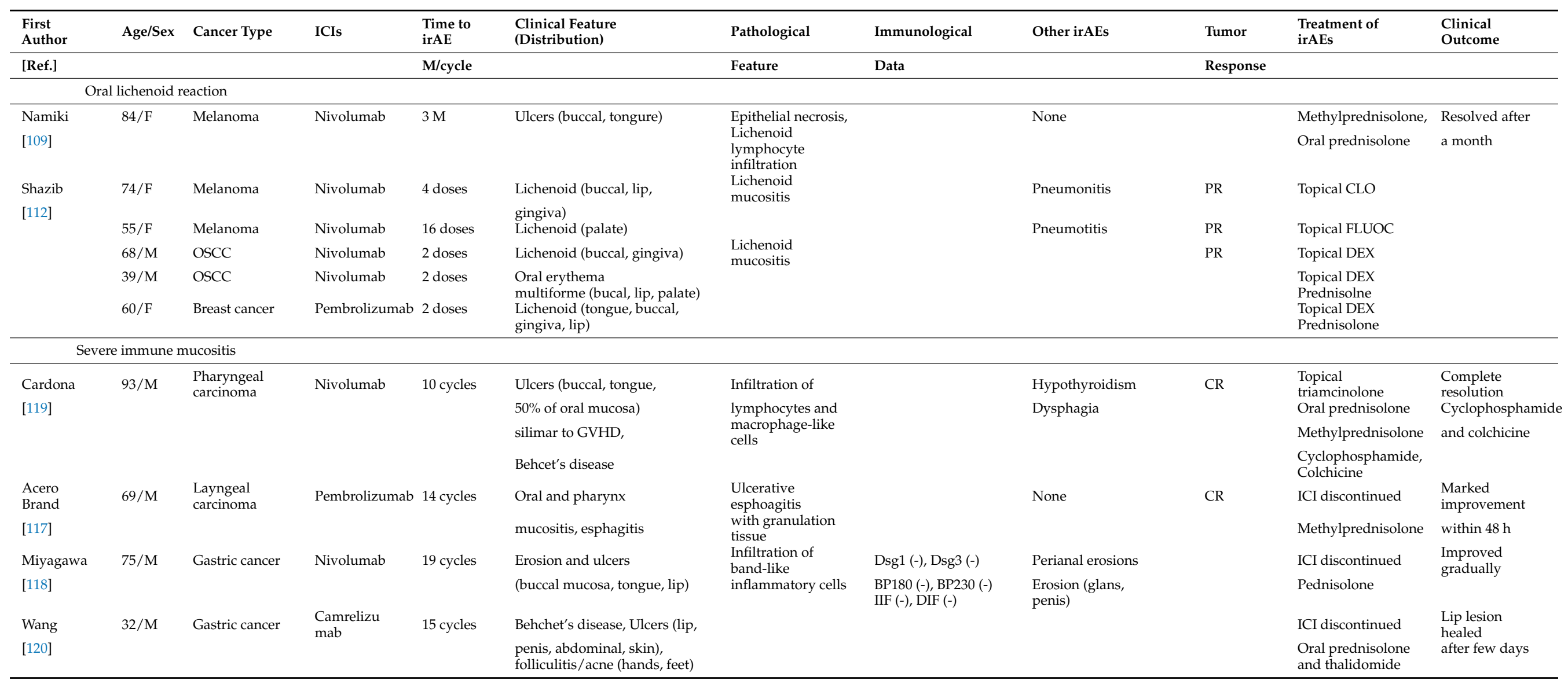


Table 2. Cont.

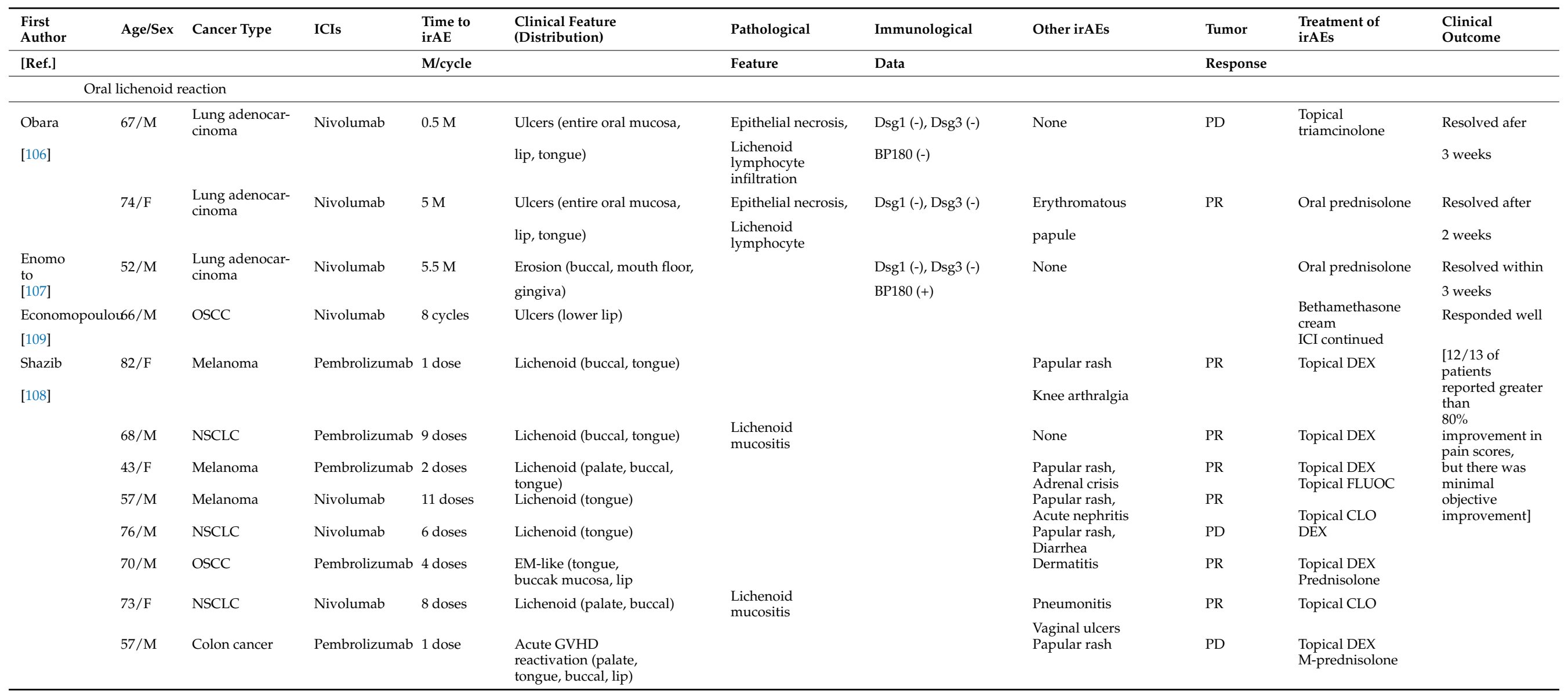


Table 2. Cont.

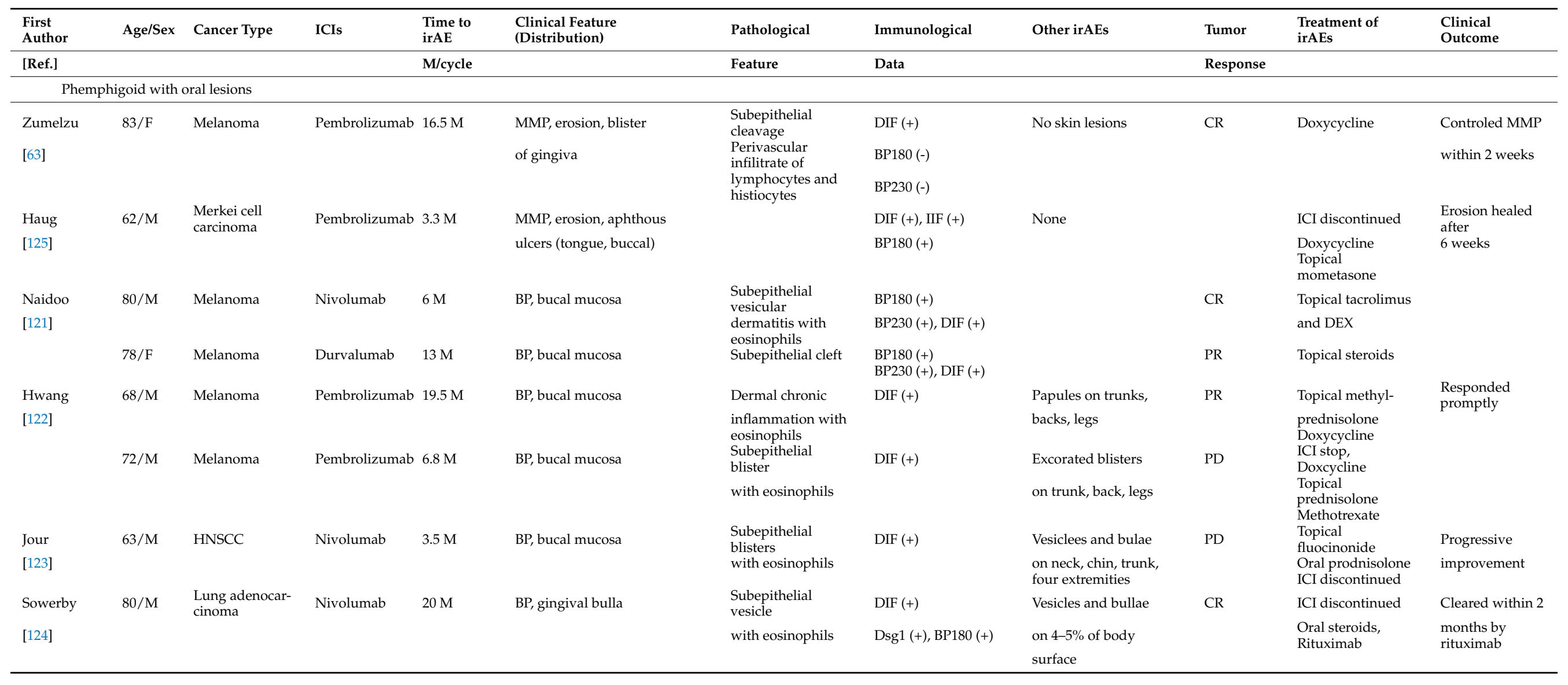


Table 2. Cont.

\begin{tabular}{|c|c|c|c|c|c|c|c|c|c|c|c|}
\hline $\begin{array}{l}\text { First } \\
\text { Author }\end{array}$ & Age/Sex & Cancer Type & ICIs & $\begin{array}{l}\text { Time to } \\
\text { irAE }\end{array}$ & $\begin{array}{l}\text { Clinical Feature } \\
\text { (Distribution) }\end{array}$ & Pathological & Immunological & Other irAEs & Tumor & $\begin{array}{l}\text { Treatment of } \\
\text { irAEs }\end{array}$ & $\begin{array}{l}\text { Clinical } \\
\text { Outcome }\end{array}$ \\
\hline [Ref.] & & & & M/cycle & & Feature & Data & & Response & & \\
\hline \multicolumn{12}{|c|}{ Phemphigoid with oral lesions } \\
\hline Wang & $70 / \mathrm{M}$ & Melanoma & Pembrolizumab & 35 cycles & $\mathrm{BP}$, hard palate & Detachment of the & $\operatorname{DIF}(+)$ & Erosions (trunk, limbs) & $C R$ & Oral prednisolone & $\begin{array}{l}\text { Disappered } \\
4 \text { weeks later }\end{array}$ \\
\hline \multirow[t]{4}{*}{$\begin{array}{l}\text { Sadik } \\
\text { [127] }\end{array}$} & $62 / \mathrm{M}$ & Melanoma & Pembrolizumab & $6.8 \mathrm{M}$ & $\begin{array}{l}\text { BP, vesicular lesions of } \\
\text { the oral mucosa }\end{array}$ & $\begin{array}{l}\text { epidermis } \\
\text { Interface } \\
\text { dermatitis, } \\
\text { Focal epidermal } \\
\text { necrosis }\end{array}$ & $\begin{array}{l}\text { IIF (IgG+) BP180 (+), } \\
\text { BP230 (+) }\end{array}$ & $\begin{array}{l}\text { Blisters (hands, legs) } \\
\text { Scattered skin papules } \\
\text { with central vesicles }\end{array}$ & $\mathrm{CR}$ & $\begin{array}{l}\text { Topical clobetasol, } \\
\text { Oral prednisolone } \\
\text {, Rituximab }\end{array}$ & $\begin{array}{l}\text { Minor } \\
\text { alleviation }\end{array}$ \\
\hline & $76 / \mathrm{M}$ & $\mathrm{RCC}$ & Nivolumab & $4.8 \mathrm{M}$ & $\mathrm{BP}$, vesicular and white & Lichenoid interface & DIF (C3+), IIF (IgG+) & Palmoplanter hyper- & SD & $\begin{array}{l}\text { Topical clobetasol } \\
\text { (skin) }\end{array}$ & $\begin{array}{l}\text { Alleviated but } \\
\text { not completely }\end{array}$ \\
\hline & & & & & $\begin{array}{l}\text { reticular lesions of the } \\
\text { oral mucosa }\end{array}$ & dermatitis & BP180 (+), BP230 (+) & $\begin{array}{l}\text { keratosis, Polygonal } \\
\text { papules, and vesicles }\end{array}$ & & $\begin{array}{l}\text { Topical } \\
\text { triamcinolone, } \\
\text { Dexpanthenol }\end{array}$ & resolved \\
\hline & \multicolumn{11}{|c|}{ Paraneoplastic pemphigus } \\
\hline Yatim & $64 / \mathrm{M}$ & Cutaneous SCC & Pembrolizumab & $0.7 \mathrm{M}$ & Paraneoplastic pemphigus, & $\begin{array}{l}\text { Suprabasal } \\
\text { acantholysis }\end{array}$ & $\operatorname{DIF}(+)$ & Extensive cutaneous & & ICI discontinued & $\begin{array}{l}\text { Complete } \\
\text { healing }\end{array}$ \\
\hline [130] & & & & & blisters, pustules, & $\begin{array}{l}\text { Intraepithelial } \\
\text { blisters }\end{array}$ & Dsg1 (+), Dsg3 (+) & involvement & & Oral prednisolone & \\
\hline
\end{tabular}

ICIs, immune checkpoint inhibitors; irAEs, immune-related adverse events; M, month; CR, complete response; PR, partial response; SD, stable disease; $\mathrm{PD}$, progressive disease; RCC, renal cell carcinoma; NR, not reported; DEX, Dexamethasone; Dsg1, desmoglein1; Dsg3, desmoglein 3; OSCC, oral squamous cell carcinoma; NSCLC, non-small cell lung cancer; FLUOC, flucinonide; CLO, Clobetasol; GVHD, graft-versus-host disease; DIF, direct immunofluorescence; IIF, indirect immunofluorescence; MMP, mucous membrane pemphidoid; BP, bullous pemphigoid; HNSCC, head and neck squamous cell carcinoma. 


\section{Conclusions}

With the use of ICIs for the treatment of HNSCC, development of a new autoimmune disease called irAEs has become a problem. The mechanisms include the disruption of immune tolerance in cellular and humoral immunity, enhanced cross-reactivity between tumor antigens and self-antigens on target organs of autoimmune disease, exacerbation of pre-existing autoimmune reactions, and Fc component-mediated cytotoxicty. ICI treatment of HNSCC patients induces various irAEs including dermatological, gastrointestinal, and endocrine disorders. Treatment of various malignancies, including HNSCC, with ICIs may result in the appearance of oral irAEs. Major oral manifestations of irAEs include Sicca syndrome, OLR, and pemphigoid. They are mostly mild, but ICI treatment is frequently discontinued and systemic corticosteroids are required to control the irAEs. Unlike pSS, ICI-induced salivary gland lesions have a lower frequency of B cells. ICI-induced OLRs may be more closely correlated with drug allergies. This suggests that these irAEs are formed by mechanisms different from pSS and OLP. For successful treatment of HNSCC with ICIs, it is necessary to elucidate the mechanisms by which irAEs occur and develop a diagnostic method and treatment for ICI-induced lesions. Among sociological factors, gender and race had a positive impact on the effectiveness of ICI by increasing effector T cell activity and PD-1 expression. Aging, on the other hand, impaired responsiveness to ICI by reducing the number of functional $\mathrm{T}$ cells and increasing toxicity [131]. It is also required to investigate how these sociological factors affect the development of irAE in the oral cavity.

Author Contributions: Conceptualization, Y.Y. and M.H.; literature collection, Y.Y. and M.H.; writingdraft preparation, review and editing, Y.Y. and M.H. All authors have read and agreed to the published version of the manuscript.

Funding: This research received no external funding.

Conflicts of Interest: The authors declare no conflict of interest.

\section{References}

1. Lee, H.T.; Lee, S.H.; Heo, Y.S. Molecular Interactions of Antibody Drugs Targeting PD-1, PD-L1, and CTLA-4 in Immuno-Oncology. Molecules 2019, 24, 1190. [CrossRef] [PubMed]

2. Shah, J.P.; Gil, Z. Current concepts in management of oral cancer-surgery. Oral Oncol. 2009, 45, 394-401. [CrossRef] [PubMed]

3. Machiels, J.P.; Lambrecht, M.; Hanin, F.X.; Duprez, T.; Gregoire, V.; Schmitz, S.; Hamoir, M. Advances in the management of squamous cell carcinoma of the head and neck. F1000Prime Rep. 2014, 6, 44. [CrossRef]

4. Jakobi, A.; Lühr, A.; Stützer, K.; Bandurska-Luque, A.; Löck, S.; Krause, M.; Baumann, M.; Perrin, R.; Richter, C. Increase in Tumor Control and Normal Tissue Complication Probabilities in Advanced Head-and-Neck Cancer for Dose-Escalated Intensity-Modulated Photon and Proton Therapy. Front. Oncol. 2015, 5, 256. [CrossRef]

5. Yura, Y.; Tada, S.; Fujita, Y.; Hamada, M. Current treatment, particle radiotherapy, and boron neutron capture therapy for advanced oral cancer in patients. Oral Sci. Int. 2019, 16, 49-68. [CrossRef]

6. Chinn, S.B.; Myers, J.N. Oral Cavity Carcinoma: Current, Controversies, and Future Directions. J. Clin. Oncol. 2015, 33, 3269-3276. [CrossRef]

7. Bernier, J.; Domenge, C.; Ozsahin, M.; Matuszewska, K.; Lefèbvre, J.L.; Greiner, R.H.; Giralt, J.; Maingon, P.; Rolland, F.; Bolla, M.; et al. Postoperative irradiation with or without concomitant chemotherapy for locally advanced head and neck cancer. N. Engl. J. Med. 2004, 350, 1945-1952. [CrossRef] [PubMed]

8. Cooper, J.S.; Pajak, T.F; Forastiere, A.A.; Jacobs, J.; Campbell, B.H.; Saxman, S.B.; Kish, J.A.; Kim, H.E.; Cmelak, A.J.; Rotman, M.; et al. Postoperative concurrent radiotherapy and chemotherapy for high-risk squamous-cell carcinoma of the head and neck. $N$. Engl. J. Med. 2004, 350, 1937-1944. [CrossRef]

9. Bonner, J.A.; Harari, P.M.; Giralt, J.; Cohen, R.B.; Jones, C.U.; Sur, R.K.; Raben, D.; Baselga, J.; Spencer, S.A.; Zhu, J.; et al. Radiotherapy plus cetuximab for locoregionally advanced head and neck cancer: 5 -year survival data from a phase 3 randomised trial, and relation between cetuximab-induced rash and survival. Lancet Oncol. 2010, 11, 21-28. [CrossRef]

10. Vermorken, J.B.; Mesia, R.; Rivera, F.; Remenar, E.; Kawecki, A.; Rottey, S.; Erfan, J.; Zabolotnyy, D.; Kienzer, H.R.; Cupissol, D.; et al. Platinum-based chemotherapy plus cetuximab in head and neck cancer. N. Engl. J. Med. 2008, 359, 1116-1127. [CrossRef]

11. Ang, K.K.; Zhang, Q.; Rosenthal, D.I.; Nguyen-Tan, P.F.; Sherman, E.J.; Weber, R.S.; Galvin, J.M.; Bonner, J.A.; Harris, J.; El-Naggar, A.K.; et al. Randomized phase III trial of concurrent accelerated radiation plus cisplatin with or without cetuximab for stage III to IV head and neck carcinoma: RTOG 0522. J. Clin. Oncol. 2014, 32, 2940-2950. [CrossRef] [PubMed] 
12. Curtis, K.K.; Ross, H.J.; Garrett, A.L.; Jizba, T.A.; Patel, A.B.; Patel, S.H.; Wong, W.W.; Halyard, M.Y.; Ko, S.J.; Kosiorek, H.E.; et al. Outcomes of patients with loco-regionally recurrent or new primary squamous cell carcinomas of the head and neck treated with curative intent reirradiation at Mayo Clinic. Radiat. Oncol. 2016, 11, 55. [CrossRef] [PubMed]

13. Marshall, H.T.; Djamgoz, M.B.A. Immuno-Oncology: Emerging Targets and Combination Therapies. Front. Oncol. 2018, 8, 315. [CrossRef]

14. Hodi, F.S.; O’Day, S.J.; McDermott, D.F.; Weber, R.W.; Sosman, J.A.; Haanen, J.B.; Gonzalez, R.; Robert, C.; Schadendorf, D.; Hassel, J.C.; et al. Improved survival with ipilimumab in patients with metastatic melanoma. N. Engl. J. Med. 2010, 363, 711-723. [CrossRef] [PubMed]

15. Robert, C.; Long, G.V.; Brady, B.; Dutriaux, C.; Maio, M.; Mortier, L.; Hassel, J.C.; Rutkowski, P.; McNeil, C.; Kalinka-Warzocha, E.; et al. Nivolumab in previously untreated melanoma without BRAF mutation. N. Engl. J. Med. 2015, 372, 320-330. [CrossRef]

16. Weber, J.S.; D’Angelo, S.P.; Minor, D.; Hodi, F.S.; Gutzmer, R.; Neyns, B.; Hoeller, C.; Khushalani, N.I.; Miller, W.H., Jr.; Lao, C.D.; et al. Nivolumab versus chemotherapy in patients with advanced melanoma who progressed after anti-CTLA-4 treatment (CheckMate 037): A randomised, controlled, open-label, phase 3 trial. Lancet Oncol. 2015, 16, 375-384. [CrossRef]

17. Ferris, R.L.; Blumenschein, G., Jr.; Fayette, J.; Guigay, J.; Colevas, A.D.; Licitra, L.; Harrington, K.; Kasper, S.; Vokes, E.E.; Even, C.; et al. Nivolumab for Recurrent Squamous-Cell Carcinoma of the Head and Neck. N. Engl. J. Med. 2016, 375, $1856-1867$. [CrossRef]

18. Seiwert, T.Y.; Burtness, B.; Mehra, R.; Weiss, J.; Berger, R.; Eder, J.P.; Heath, K.; McClanahan, T.; Lunceford, J.; Gause, C.; et al. Safety and clinical activity of pembrolizumab for treatment of recurrent or metastatic squamous cell carcinoma of the head and neck (KEYNOTE-012): An open-label, multicentre, phase 1b trial. Lancet Oncol. 2016, 17, 956-965. [CrossRef]

19. Bauml, J.; Seiwert, T.Y.; Pfister, D.G.; Worden, F.; Liu, S.V.; Gilbert, J.; Saba, N.F.; Weiss, J.; Wirth, L.; Sukari, A.; et al. Pembrolizumab for Platinum- and Cetuximab-Refractory Head and Neck Cancer: Results From a Single-Arm, Phase II Study. J. Clin. Oncol. 2017, 35, 1542-1549. [CrossRef]

20. Saba, N.F.; Blumenschein, G., Jr.; Guigay, J.; Licitra, L.; Fayette, J.; Harrington, K.J.; Kiyota, N.; Gillison, M.L.; Ferris, R.L.; Jayaprakash, V.; et al. Nivolumab versus investigator's choice in patients with recurrent or metastatic squamous cell carcinoma of the head and neck: Efficacy and safety in CheckMate 141 by age. Oral Oncol. 2019, 96, 7-14. [CrossRef]

21. Burtness, B.; Harrington, K.J.; Greil, R.; Soulières, D.; Tahara, M.; de Castro, G., Jr.; Psyrri, A.; Basté, N.; Neupane, P.; Bratland, Å.; et al. Pembrolizumab alone or with chemotherapy versus cetuximab with chemotherapy for recurrent or metastatic squamous cell carcinoma of the head and neck (KEYNOTE-048): A randomised, open-label, phase 3 study. Lancet 2019, 394, 1915-1928. [CrossRef]

22. Matsuo, M.; Yasumatsu, R.; Masuda, M.; Toh, S.; Wakasaki, T.; Hashimoto, K.; Taura, M.; Uchi, R.; Nakagawa, T. Relationship between immune-related adverse events and the long-term outcomes in recurrent/metastatic head and neck squamous cell carcinoma treated with nivolumab. Oral Oncol. 2020, 101, 104525. [CrossRef] [PubMed]

23. Pfister, D.G.; Spencer, S.; Adelstein, D.; Adkins, D.; Anzai, Y.; Brizel, D.M.; Bruce, J.Y.; Busse, P.M.; Caudell, J.J.; Cmelak, A.J.; et al. Head and Neck Cancers, Version 2.2020, NCCN Clinical Practice Guidelines in Oncology. J. Natl. Compr. Cancer Netw. 2020, 18, 873-898. [CrossRef] [PubMed]

24. Weinmann, S.C.; Pisetsky, D.S. Mechanisms of immune-related adverse events during the treatment of cancer with immune checkpoint inhibitors. Rheumatology 2019, 58, vii59-vii67. [CrossRef] [PubMed]

25. Brahmer, J.R.; Lacchetti, C.; Schneider, B.J.; Atkins, M.B.; Brassil, K.J.; Caterino, J.M.; Chau, I.; Ernstoff, M.S.; Gardner, J.M.; Ginex, P.; et al. Management of Immune-Related Adverse Events in Patients Treated With Immune Checkpoint Inhibitor Therapy: American Society of Clinical Oncology Clinical Practice Guideline. J. Clin. Oncol. 2018, 36, 1714-1768. [CrossRef] [PubMed]

26. Saccucci, M.; Di Carlo, G.; Bossù, M.; Giovarruscio, F.; Salucci, A.; Polimeni, A. Autoimmune Diseases and Their Manifestations on Oral Cavity: Diagnosis and Clinical Management. J. Immunol. Res. 2018, 2018, 6061825. [CrossRef] [PubMed]

27. Gualtierotti, R.; Marzano, A.V.; Spadari, F.; Cugno, M. Main Oral Manifestations in Immune-Mediated and Inflammatory Rheumatic Diseases. J. Clin. Med. 2018, 8, 21. [CrossRef] [PubMed]

28. Dyck, L.; Mills, K.H.G. Immune checkpoints and their inhibition in cancer and infectious diseases. Eur J. Immunol. 2017, 47, 765-779. [CrossRef] [PubMed]

29. Fazilleau, N.; Mark, L.; McHeyzer-Williams, L.J.; McHeyzer-Williams, M.G. Follicular helper T cells: Lineage and location. Immunity 2009, 30, 324-335. [CrossRef]

30. Craft, J.E. Follicular helper T cells in immunity and systemic autoimmunity. Nat. Rev. Rheumatol. 2012, 8, 337-347. [CrossRef] [PubMed]

31. van der Merwe, P.A.; Bodian, D.L.; Daenke, S.; Linsley, P.; Davis, S.J. CD80 (B7-1) binds both CD28 and CTLA-4 with a low affinity and very fast kinetics. J. Exp. Med. 1997, 185, 393-403. [CrossRef] [PubMed]

32. Francisco, L.M.; Sage, P.T.; Sharpe, A.H. The PD-1 pathway in tolerance and autoimmunity. Immunol. Rev. 2010, 236, 219-242. [CrossRef] [PubMed]

33. Zhu, Y.; Zou, L.; Liu, Y.C. T follicular helper cells, T follicular regulatory cells and autoimmunity. Int. Immunol. 2016, 28, 173-179. [CrossRef] [PubMed]

34. Sage, P.T.; Schildberg, F.A.; Sobel, R.A.; Kuchroo, V.K.; Freeman, G.J.; Sharpe, A.H. Dendritic Cell PD-L1 Limits Autoimmunity and Follicular T Cell Differentiation and Function. J. Immunol. 2018, 200, 2592-2602. [CrossRef] [PubMed] 
35. Zhang, M.; Xia, L.; Yang, Y.; Liu, S.; Ji, P.; Wang, S.; Chen, Y.; Liu, Z.; Zhang, Y.; Lu, S.; et al. PD-1 blockade augments humoral immunity through ICOS-mediated CD4(+) T cell instruction. Int. Immunopharmacol. 2019, 66, 127-138. [CrossRef]

36. Linterman, M.A.; Hill, D.L. Can follicular helper T cells be targeted to improve vaccine efficacy? F1000Research 2016, 5. [CrossRef]

37. Stebegg, M.; Kumar, S.D.; Silva-Cayetano, A.; Fonseca, V.R.; Linterman, M.A.; Graca, L. Regulation of the Germinal Center Response. Front. Immunol. 2018, 9, 2469. [CrossRef]

38. Gong, Y.; Tong, J.; Wang, S. Are Follicular Regulatory T Cells Involved in Autoimmune Diseases? Front. Immunol. 2017, 8, 1790. [CrossRef]

39. Sage, P.T.; Sharpe, A.H. T follicular regulatory cells in the regulation of B cell responses. Trends Immunol. 2015, 36, 410-418. [CrossRef]

40. Byrne, K.T.; Turk, M.J. New perspectives on the role of vitiligo in immune responses to melanoma. Oncotarget 2011, 2, 684-694. [CrossRef]

41. Hara, I.; Takechi, Y.; Houghton, A.N. Implicating a role for immune recognition of self in tumor rejection: Passive immunization against the brown locus protein. J. Exp. Med. 1995, 182, 1609-1614. [CrossRef] [PubMed]

42. Ram, M.; Shoenfeld, Y. Harnessing autoimmunity (vitiligo) to treat melanoma: A myth or reality? Ann. N. Y. Acad. Sci. 2007, 1110, 410-425. [CrossRef] [PubMed]

43. Burke, K.P.; Grebinoski, S.; Sharpe, A.H.; Vignali, D.A.A. Understanding adverse events of immunotherapy: A mechanistic perspective. J. Exp. Med. 2021, 218. [CrossRef] [PubMed]

44. Iwama, S.; De Remigis, A.; Callahan, M.K.; Slovin, S.F.; Wolchok, J.D.; Caturegli, P. Pituitary expression of CTLA-4 mediates hypophysitis secondary to administration of CTLA-4 blocking antibody. Sci. Transl. Med. 2014, 6, 230ra245. [CrossRef]

45. Abdel-Wahab, N.; Shah, M.; Suarez-Almazor, M.E. Adverse Events Associated with Immune Checkpoint Blockade in Patients with Cancer: A Systematic Review of Case Reports. PLoS ONE 2016, 11, e0160221. [CrossRef]

46. Siu, L.L.; Even, C.; Mesía, R.; Remenar, E.; Daste, A.; Delord, J.P.; Krauss, J.; Saba, N.F.; Nabell, L.; Ready, N.E.; et al. Safety and Efficacy of Durvalumab With or Without Tremelimumab in Patients With PD-L1-Low/Negative Recurrent or Metastatic HNSCC: The Phase 2 CONDOR Randomized Clinical Trial. JAMA Oncol. 2019, 5, 195-203. [CrossRef]

47. Parry, R.V.; Harris, S.J.; Ward, S.G. Fine tuning T lymphocytes: A role for the lipid phosphatase SHIP-1. Biochim. Biophys. Acta 2010, 1804, 592-597. [CrossRef]

48. von Euw, E.; Chodon, T.; Attar, N.; Jalil, J.; Koya, R.C.; Comin-Anduix, B.; Ribas, A. CTLA4 blockade increases Th17 cells in patients with metastatic melanoma. J. Transl. Med. 2009, 7, 35. [CrossRef]

49. Granier, C.; De Guillebon, E.; Blanc, C.; Roussel, H.; Badoual, C.; Colin, E.; Saldmann, A.; Gey, A.; Oudard, S.; Tartour, E. Mechanisms of action and rationale for the use of checkpoint inhibitors in cancer. ESMO Open 2017, 2, e000213. [CrossRef]

50. Kumar, P.; Bhattacharya, P.; Prabhakar, B.S. A comprehensive review on the role of co-signaling receptors and Treg homeostasis in autoimmunity and tumor immunity. J. Autoimmun. 2018, 95, 77-99. [CrossRef]

51. Selby, M.J.; Engelhardt, J.J.; Quigley, M.; Henning, K.A.; Chen, T.; Srinivasan, M.; Korman, A.J. Anti-CTLA-4 antibodies of IgG2a isotype enhance antitumor activity through reduction of intratumoral regulatory T cells. Cancer Immunol. Res. 2013, 1, 32-42. [CrossRef]

52. Fiegle, E.; Doleschel, D.; Koletnik, S.; Rix, A.; Weiskirchen, R.; Borkham-Kamphorst, E.; Kiessling, F.; Lederle, W. Dual CTLA-4 and PD-L1 Blockade Inhibits Tumor Growth and Liver Metastasis in a Highly Aggressive Orthotopic Mouse Model of Colon Cancer. Neoplasia 2019, 21, 932-944. [CrossRef] [PubMed]

53. Yamaguchi, K.; Mishima, K.; Ohmura, H.; Hanamura, F.; Ito, M.; Nakano, M.; Tsuchihashi, K.; Ota, S.I.; Wada, N.; Uchi, H.; et al. Activation of central/effector memory T cells and T-helper 1 polarization in malignant melanoma patients treated with anti-programmed death-1 antibody. Cancer Sci. 2018, 109, 3032-3042. [CrossRef] [PubMed]

54. Yoshida, K.; Okamoto, M.; Sasaki, J.; Kuroda, C.; Ishida, H.; Ueda, K.; Ideta, H.; Kamanaka, T.; Sobajima, A.; Takizawa, T.; et al. Anti-PD-1 antibody decreases tumour-infiltrating regulatory T cells. BMC Cancer 2020, 20, 25. [CrossRef] [PubMed]

55. Park, H.J.; Park, J.S.; Jeong, Y.H.; Son, J.; Ban, Y.H.; Lee, B.H.; Chen, L.; Chang, J.; Chung, D.H.; Choi, I.; et al. PD-1 upregulated on regulatory $\mathrm{T}$ cells during chronic virus infection enhances the suppression of $\mathrm{CD}^{+} \mathrm{T}$ cell immune response via the interaction with PD-L1 expressed on CD8 ${ }^{+}$T cells. J. Immunol. 2015, 194, 5801-5811. [CrossRef]

56. Toor, S.M.; Syed Khaja, A.S.; Alkurd, I.; Elkord, E. In-vitro effect of pembrolizumab on different T regulatory cell subsets. Clin. Exp. Immunol. 2018, 191, 189-197. [CrossRef]

57. Kamada, T.; Togashi, Y.; Tay, C.; Ha, D.; Sasaki, A.; Nakamura, Y.; Sato, E.; Fukuoka, S.; Tada, Y.; Tanaka, A.; et al. PD-1(+) regulatory $\mathrm{T}$ cells amplified by PD-1 blockade promote hyperprogression of cancer. Proc. Natl. Acad. Sci. USA 2019, 116, 9999-10008. [CrossRef]

58. Larkin, J.; Chiarion-Sileni, V.; Gonzalez, R.; Grob, J.J.; Cowey, C.L.; Lao, C.D.; Schadendorf, D.; Dummer, R.; Smylie, M.; Rutkowski, P.; et al. Combined Nivolumab and Ipilimumab or Monotherapy in Untreated Melanoma. N. Engl. J. Med. 2015, 373, 23-34. [CrossRef]

59. Willsmore, Z.N.; Harris, R.J.; Crescioli, S.; Hussein, K.; Kakkassery, H.; Thapa, D.; Cheung, A.; Chauhan, J.; Bax, H.J.; Chenoweth, A.; et al. B Cells in Patients With Melanoma: Implications for Treatment With Checkpoint Inhibitor Antibodies. Front. Immunol. 2020, 11, 622442. [CrossRef] 
60. Osorio, J.C.; Ni, A.; Chaft, J.E.; Pollina, R.; Kasler, M.K.; Stephens, D.; Rodriguez, C.; Cambridge, L.; Rizvi, H.; Wolchok, J.D.; et al. Antibody-mediated thyroid dysfunction during T-cell checkpoint blockade in patients with non-small-cell lung cancer. Ann. Oncol. 2017, 28, 583-589. [CrossRef]

61. Hughes, J.; Vudattu, N.; Sznol, M.; Gettinger, S.; Kluger, H.; Lupsa, B.; Herold, K.C. Precipitation of autoimmune diabetes with anti-PD-1 immunotherapy. Diabetes Care 2015, 38, e55-e57. [CrossRef] [PubMed]

62. Stamatouli, A.M.; Quandt, Z.; Perdigoto, A.L.; Clark, P.L.; Kluger, H.; Weiss, S.A.; Gettinger, S.; Sznol, M.; Young, A.; Rushakoff, R.; et al. Collateral Damage: Insulin-Dependent Diabetes Induced With Checkpoint Inhibitors. Diabetes 2018, 67, 1471-1480. [CrossRef] [PubMed]

63. Zumelzu, C.; Alexandre, M.; Le Roux, C.; Weber, P.; Guyot, A.; Levy, A.; Aucouturier, F.; Mignot-Grootenboer, S.; Caux, F.; Maubec, E.; et al. Mucous Membrane Pemphigoid, Bullous Pemphigoid, and Anti-programmed Death-1/ Programmed Death-Ligand 1: A Case Report of an Elderly Woman With Mucous Membrane Pemphigoid Developing After Pembrolizumab Therapy for Metastatic Melanoma and Review of the Literature. Front. Med. 2018, 5, 268. [CrossRef]

64. Hasan Ali, O.; Bomze, D.; Ring, S.S.; Berner, F.; Fässler, M.; Diem, S.; Abdou, M.T.; Hammers, C.; Emtenani, S.; Braun, A.; et al. BP180-specific IgG is associated with skin adverse events, therapy response, and overall survival in non-small cell lung cancer patients treated with checkpoint inhibitors. J. Am. Acad. Dermatol. 2020, 82, 854-861. [CrossRef] [PubMed]

65. Das, R.; Bar, N.; Ferreira, M.; Newman, A.M.; Zhang, L.; Bailur, J.K.; Bacchiocchi, A.; Kluger, H.; Wei, W.; Halaban, R.; et al. Early B cell changes predict autoimmunity following combination immune checkpoint blockade. J. Clin. Invest. 2018, 128, 715-720. [CrossRef]

66. Fife, B.T.; Pauken, K.E.; Eagar, T.N.; Obu, T.; Wu, J.; Tang, Q.; Azuma, M.; Krummel, M.F.; Bluestone, J.A. Interactions between PD-1 and PD-L1 promote tolerance by blocking the TCR-induced stop signal. Nat. Immunol 2009, 10, 1185-1192. [CrossRef]

67. Good-Jacobson, K.L.; Szumilas, C.G.; Chen, L.; Sharpe, A.H.; Tomayko, M.M.; Shlomchik, M.J. PD-1 regulates germinal center B cell survival and the formation and affinity of long-lived plasma cells. Nat. Immunol. 2010, 11, 535-542. [CrossRef]

68. June, C.H.; Warshauer, J.T.; Bluestone, J.A. Is autoimmunity the Achilles' heel of cancer immunotherapy? Nat. Med. 2017, 23, 540-547. [CrossRef]

69. Passat, T.; Touchefeu, Y.; Gervois, N.; Jarry, A.; Bossard, C.; Bennouna, J. Physiopathological mechanisms of immune-related adverse events induced by anti-CTLA-4, anti-PD-1 and anti-PD-L1 antibodies in cancer treatment. Bull. Cancer 2018, 105, 1033-1041. [CrossRef]

70. de Moel, E.C.; Rozeman, E.A.; Kapiteijn, E.H.; Verdegaal, E.M.E.; Grummels, A.; Bakker, J.A.; Huizinga, T.W.J.; Haanen, J.B.; Toes, R.E.M.; van der Woude, D. Autoantibody Development under Treatment with Immune-Checkpoint Inhibitors. Cancer Immunol. Res. 2019, 7, 6-11. [CrossRef]

71. Menzies, A.M.; Johnson, D.B.; Ramanujam, S.; Atkinson, V.G.; Wong, A.N.M.; Park, J.J.; McQuade, J.L.; Shoushtari, A.N.; Tsai, K.K.; Eroglu, Z.; et al. Anti-PD-1 therapy in patients with advanced melanoma and preexisting autoimmune disorders or major toxicity with ipilimumab. Ann. Oncol. 2017, 28, 368-376. [CrossRef] [PubMed]

72. Eppihimer, M.J.; Gunn, J.; Freeman, G.J.; Greenfield, E.A.; Chernova, T.; Erickson, J.; Leonard, J.P. Expression and regulation of the PD-L1 immunoinhibitory molecule on microvascular endothelial cells. Microcirculation 2002, 9, 133-145. [CrossRef] [PubMed]

73. Keir, M.E.; Liang, S.C.; Guleria, I.; Latchman, Y.E.; Qipo, A.; Albacker, L.A.; Koulmanda, M.; Freeman, G.J.; Sayegh, M.H.; Sharpe, A.H. Tissue expression of PD-L1 mediates peripheral T cell tolerance. J. Exp. Med. 2006, 203, 883-895. [CrossRef] [PubMed]

74. Sharpe, A.H.; Wherry, E.J.; Ahmed, R.; Freeman, G.J. The function of programmed cell death 1 and its ligands in regulating autoimmunity and infection. Nat. Immunol. 2007, 8, 239-245. [CrossRef] [PubMed]

75. Yamauchi, I.; Yasoda, A.; Matsumoto, S.; Sakamori, Y.; Kim, Y.H.; Nomura, M.; Otsuka, A.; Yamasaki, T.; Saito, R.; Kitamura, M.; et al. Incidence, features, and prognosis of immune-related adverse events involving the thyroid gland induced by nivolumab. PLoS ONE 2019, 14, e0216954. [CrossRef] [PubMed]

76. Dubin, K.; Callahan, M.K.; Ren, B.; Khanin, R.; Viale, A.; Ling, L.; No, D.; Gobourne, A.; Littmann, E.; Huttenhower, C.; et al. Intestinal microbiome analyses identify melanoma patients at risk for checkpoint-blockade-induced colitis. Nat. Commun. 2016, 7, 10391. [CrossRef]

77. Naqash, A.R.; Kihn-Alarcón, A.J.; Stavraka, C.; Kerrigan, K.; Maleki Vareki, S.; Pinato, D.J.; Puri, S. The role of gut microbiome in modulating response to immune checkpoint inhibitor therapy in cancer. Ann. Transl Med. 2021, 9, 1034. [CrossRef]

78. Wang, T.; Zheng, N.; Luo, Q.; Jiang, L.; He, B.; Yuan, X.; Shen, L. Probiotics Lactobacillus reuteri Abrogates Immune Checkpoint Blockade-Associated Colitis by Inhibiting Group 3 Innate Lymphoid Cells. Front. Immunol. 2019, 10, 1235. [CrossRef]

79. Pitt, J.M.; Vétizou, M.; Gomperts Boneca, I.; Lepage, P.; Chamaillard, M.; Zitvogel, L. Enhancing the clinical coverage and anticancer efficacy of immune checkpoint blockade through manipulation of the gut microbiota. Oncoimmunology 2017, 6, e1132137. [CrossRef]

80. Kitamoto, S.; Nagao-Kitamoto, H.; Hein, R.; Schmidt, T.M.; Kamada, N. The Bacterial Connection between the Oral Cavity and the Gut Diseases. J. Dent. Res. 2020, 99, 1021-1029. [CrossRef]

81. Concha-Benavente, F.; Srivastava, R.M.; Trivedi, S.; Lei, Y.; Chandran, U.; Seethala, R.R.; Freeman, G.J.; Ferris, R.L. Identification of the Cell-Intrinsic and -Extrinsic Pathways Downstream of EGFR and IFN $\gamma$ That Induce PD-L1 Expression in Head and Neck Cancer. Cancer Res. 2016, 76, 1031-1043. [CrossRef] [PubMed] 
82. Kiyota, N.; Hasegawa, Y.; Takahashi, S.; Yokota, T.; Yen, C.J.; Iwae, S.; Shimizu, Y.; Hong, R.L.; Goto, M.; Kang, J.H.; et al. A randomized, open-label, Phase III clinical trial of nivolumab vs. therapy of investigator's choice in recurrent squamous cell carcinoma of the head and neck: A subanalysis of Asian patients versus the global population in checkmate 141. Oral Oncol. 2017, 73, 138-146. [CrossRef] [PubMed]

83. Mehra, R.; Seiwert, T.Y.; Gupta, S.; Weiss, J.; Gluck, I.; Eder, J.P.; Burtness, B.; Tahara, M.; Keam, B.; Kang, H.; et al. Efficacy and safety of pembrolizumab in recurrent/metastatic head and neck squamous cell carcinoma: Pooled analyses after long-term follow-up in KEYNOTE-012. Br. J. Cancer 2018, 119, 153-159. [CrossRef] [PubMed]

84. Okamoto, I.; Sato, H.; Kondo, T.; Koyama, N.; Fushimi, C.; Okada, T.; Miura, K.; Matsuki, T.; Yamashita, T.; Omura, G.; et al. Efficacy and safety of nivolumab in 100 patients with recurrent or metastatic head and neck cancer - a retrospective multicentre study. Acta Otolaryngol. 2019, 139, 918-925. [CrossRef]

85. Vokes, E.E.; Ready, N.; Felip, E.; Horn, L.; Burgio, M.A.; Antonia, S.J.; Arén Frontera, O.; Gettinger, S.; Holgado, E.; Spigel, D.; et al. Nivolumab versus docetaxel in previously treated advanced non-small-cell lung cancer (CheckMate 017 and CheckMate 057): 3-year update and outcomes in patients with liver metastases. Ann. Oncol. 2018, 29, 959-965. [CrossRef]

86. Zandberg, D.P.; Algazi, A.P.; Jimeno, A.; Good, J.S.; Fayette, J.; Bouganim, N.; Ready, N.E.; Clement, P.M.; Even, C.; Jang, R.W.; et al. Durvalumab for recurrent or metastatic head and neck squamous cell carcinoma: Results from a single-arm, phase II study in patients with $\geq 25 \%$ tumour cell PD-L1 expression who have progressed on platinum-based chemotherapy. Eur. J. Cancer 2019, 107, 142-152. [CrossRef]

87. Brito-Zerón, P.; Baldini, C.; Bootsma, H.; Bowman, S.J.; Jonsson, R.; Mariette, X.; Sivils, K.; Theander, E.; Tzioufas, A.; RamosCasals, M. Sjögren syndrome. Nat. Rev. Dis. Primers 2016, 2, 16047. [CrossRef]

88. Jonsson, R.; Brokstad, K.A.; Jonsson, M.V.; Delaleu, N.; Skarstein, K. Current concepts on Sjögren's syndrome - classification criteria and biomarkers. Eur. J. Oral. Sci. 2018, 126 Suppl 1, 37-48. [CrossRef]

89. Verstappen, G.M.; Corneth, O.B.J.; Bootsma, H.; Kroese, F.G.M. Th17 cells in primary Sjögren's syndrome: Pathogenicity and plasticity. J. Autoimmun. 2018, 87, 16-25. [CrossRef]

90. Parisis, D.; Chivasso, C.; Perret, J.; Soyfoo, M.S.; Delporte, C. Current State of Knowledge on Primary Sjögren's Syndrome, an Autoimmune Exocrinopathy. J. Clin. Med. 2020, 9, 2299. [CrossRef]

91. Reed, J.H.; Verstappen, G.M.; Rischmueller, M.; Bryant, V.L. When B cells break bad: Development of pathogenic B cells in Sjögren's syndrome. Clin. Exp. Rheumatol. 2020, 38 (Suppl. 126), 271-282. [PubMed]

92. Ramos-Casals, M.; Maria, A.; Suárez-Almazor, M.E.; Lambotte, O.; Fisher, B.A.; Hernández-Molina, G.; Guilpain, P.; Pundole, X.; Flores-Chávez, A.; Baldini, C.; et al. Sicca/Sjögren's syndrome triggered by PD-1/PD-L1 checkpoint inhibitors. Data from the International ImmunoCancer Registry (ICIR). Clin. Exp. Rheumatol. 2019, 37 (Suppl. 118), 114-122.

93. Le Burel, S.; Champiat, S.; Mateus, C.; Marabelle, A.; Michot, J.M.; Robert, C.; Belkhir, R.; Soria, J.C.; Laghouati, S.; Voisin, A.L.; et al. Prevalence of immune-related systemic adverse events in patients treated with anti-Programmed cell Death $1 /$ antiProgrammed cell Death-Ligand 1 agents: A single-centre pharmacovigilance database analysis. Eur. J. Cancer 2017, 82, 34-44. [CrossRef] [PubMed]

94. Cappelli, L.C.; Gutierrez, A.K.; Baer, A.N.; Albayda, J.; Manno, R.L.; Haque, U.; Lipson, E.J.; Bleich, K.B.; Shah, A.A.; Naidoo, J.; et al. Inflammatory arthritis and sicca syndrome induced by nivolumab and ipilimumab. Ann. Rheum. Dis. 2017, 76, 43-50. [CrossRef] [PubMed]

95. Teyssonneau, D.; Cousin, S.; Italiano, A. Gougerot-Sjogren-like syndrome under PD-1 inhibitor treatment. Ann. Oncol. 2017, 28, 3108. [CrossRef] [PubMed]

96. Calabrese, C.; Kirchner, E.; Kontzias, A.; Velcheti, V.; Calabrese, L.H. Rheumatic immune-related adverse events of checkpoint therapy for cancer: Case series of a new nosological entity. RMD Open 2017, 3, e000412. [CrossRef]

97. Takahashi, S.; Chieko, X.; Sakai, T.; Hirose, S.; Nakamura, M. Nivolumab-induced sialadenitis. Respirol. Case Rep. 2018, 6, e00322. [CrossRef]

98. Warner, B.M.; Baer, A.N.; Lipson, E.J.; Allen, C.; Hinrichs, C.; Rajan, A.; Pelayo, E.; Beach, M.; Gulley, J.L.; Madan, R.A.; et al. Sicca Syndrome Associated with Immune Checkpoint Inhibitor Therapy. Oncologist 2019, 24, 1259-1269. [CrossRef]

99. Ortiz Brugués, A.; Sibaud, V.; Herbault-Barrés, B.; Betrian, S.; Korakis, I.; De Bataille, C.; Gomez-Roca, C.; Epstein, J.; Vigarios, E. Sicca Syndrome Induced by Immune Checkpoint Inhibitor Therapy: Optimal Management Still Pending. Oncologist 2020, 25, e391-e395. [CrossRef]

100. Higashi, T.; Miyamoto, H.; Yoshida, R.; Furuta, Y.; Nagaoka, K.; Naoe, H.; Naito, H.; Nakayama, H.; Tanaka, M. Sjögren's Syndrome as an Immune-related Adverse Event of Nivolumab Treatment for Gastric Cancer. Intern. Med. 2020, 59, $2499-2504$. [CrossRef]

101. Costa, S.; Schutz, S.; Cornec, D.; Uguen, A.; Quintin-Roué, I.; Lesourd, A.; Berthelot, J.M.; Hachulla, E.; Hatron, P.Y.; Goeb, V.; et al. B-cell and T-cell quantification in minor salivary glands in primary Sjögren's syndrome: Development and validation of a pixel-based digital procedure. Arthritis Res. Ther. 2016, 18, 21. [CrossRef] [PubMed]

102. Alessandri, C.; Ciccia, F.; Priori, R.; Astorri, E.; Guggino, G.; Alessandro, R.; Rizzo, A.; Conti, F.; Minniti, A.; Barbati, C.; et al. CD4 T lymphocyte autophagy is upregulated in the salivary glands of primary Sjögren's syndrome patients and correlates with focus score and disease activity. Arthritis Res. Ther. 2017, 19, 178. [CrossRef] [PubMed] 
103. Lodi, G.; Scully, C.; Carrozzo, M.; Griffiths, M.; Sugerman, P.B.; Thongprasom, K. Current controversies in oral lichen planus: Report of an international consensus meeting. Part 1. Viral infections and etiopathogenesis. Oral Surg. Oral Med. Oral Pathol. Oral Radiol. Endod. 2005, 100, 40-51. [CrossRef] [PubMed]

104. Al-Hashimi, I.; Schifter, M.; Lockhart, P.B.; Wray, D.; Brennan, M.; Migliorati, C.A.; Axéll, T.; Bruce, A.J.; Carpenter, W.; Eisenberg, E.; et al. Oral lichen planus and oral lichenoid lesions: Diagnostic and therapeutic considerations. Oral Surg. Oral Med. Oral Pathol. Oral Radiol. Endod. 2007, 103 (Suppl. 25), e1-e12. [CrossRef] [PubMed]

105. Juneja, M.; Mahajan, S.; Rao, N.N.; George, T.; Boaz, K. Histochemical analysis of pathological alterations in oral lichen planus and oral lichenoid lesions. J. Oral Sci. 2006, 48, 185-193. [CrossRef]

106. van der Waal, I. Oral lichen planus and oral lichenoid lesions; a critical appraisal with emphasis on the diagnostic aspects. Med. Oral Patol. Oral Cir. Bucal. 2009, 14, E310-E314.

107. Shi, V.J.; Rodic, N.; Gettinger, S.; Leventhal, J.S.; Neckman, J.P.; Girardi, M.; Bosenberg, M.; Choi, J.N. Clinical and Histologic Features of Lichenoid Mucocutaneous Eruptions Due to Anti-Programmed Cell Death 1 and Anti-Programmed Cell Death Ligand 1 Immunotherapy. JAMA Dermatol. 2016, 152, 1128-1136. [CrossRef]

108. Sibaud, V.; Eid, C.; Belum, V.R.; Combemale, P.; Barres, B.; Lamant, L.; Mourey, L.; Gomez-Roca, C.; Estilo, C.L.; Motzer, R.; et al. Oral lichenoid reactions associated with anti-PD-1/PD-L1 therapies: Clinicopathological findings. J. Eur. Acad. Dermatol. Venereol. 2017, 31, e464-e469. [CrossRef]

109. Namiki, T.; Hanafusa, T.; Ueno, M.; Miura, K.; Yokozeki, H. Severe Oral Ulcers Associated With Nivolumab Treatment. JAMA Dermatol. 2017, 153, 235-237. [CrossRef]

110. Obara, K.; Masuzawa, M.; Amoh, Y. Oral lichenoid reaction showing multiple ulcers associated with anti-programmed death cell receptor-1 treatment: A report of two cases and published work review. J. Dermatol. 2018, 45, 587-591. [CrossRef]

111. Enomoto, Y.; Nakatani, H.; Kondo, S.; Kasai, T.; Tsuchiya, Y. Drug-induced oral lichenoid reaction during nivolumab therapy. Int. J. Oral Maxillofac. Surg. 2019, 48, 488-491. [CrossRef] [PubMed]

112. Shazib, M.A.; Woo, S.B.; Sroussi, H.; Carvo, I.; Treister, N.; Farag, A.; Schoenfeld, J.; Haddad, R.; LeBoeuf, N.; Villa, A. Oral immune-related adverse events associated with PD-1 inhibitor therapy: A case series. Oral Dis. 2020, 26, 325-333. [CrossRef] [PubMed]

113. Economopoulou, P.; Nicolatou-Galitis, O.; Kotsantis, I.; Psyrri, A. Nivolumab-related lichen planus of the lip in a patient with head and neck cancer. Oral Oncol. 2020, 104, 104623. [CrossRef] [PubMed]

114. Aminzadeh, A.; Jahanshahi, G.; Ahmadi, M. A retrospective comparative study on clinico-pathologic features of oral lichen planus and oral lichenoid lesions. Dent. Res. J. (Isfahan) 2013, 10, 168-172. [CrossRef]

115. Kuten-Shorrer, M.; Hochberg, E.P.; Woo, S.B. Lichenoid mucosal reaction to rituximab. Oncologist 2014, 19, e12-e13. [CrossRef] [PubMed]

116. Zembiec-Wheeler, B.; Lott-Limbach, A.; Malmström, H.; Elad, S. Oral lichenoid reactions may possibly be associated with abatacept: A case report and literature update. Oral Surg. Oral Med. Oral Pathol. Oral Radiol. 2018, 126, e245-e251. [CrossRef]

117. Acero Brand, F.Z.; Suter, N.; Adam, J.P.; Faulques, B.; Maietta, A.; Soulières, D.; Blais, N. Severe immune mucositis and esophagitis in metastatic squamous carcinoma of the larynx associated with pembrolizumab. J. Immunother. Cancer 2018, 6, 22. [CrossRef]

118. Miyagawa, F.; Nakajima, A.; Ohyama, S.I.; Aoki, Y.; Nishikawa, M.; Nakamura, Y.; Hashimoto, T.; Asada, H. Mucosal Lichen Planus Mimicking Mucosal Lesions in Stevens-Johnson Syndrome after Nivolumab Therapy. Acta Derm. Venereol. 2019, 99, 687-688. [CrossRef]

119. Cardona, A.F.; Ruiz-Patiño, A.; Ricaurte, L.; Zatarain-Barrón, Z.L.; Barrón, F.; Arrieta, O. Chronic and Severe Non-Lichenoid Oral Ulcers Induced by Nivolumab - Diagnostic and Therapeutic Challenge: A Case Report. Case Rep. Oncol. 2020, 13, 314-320. [CrossRef]

120. Wang, D.; Zhang, S.; Ding, P.; Zhao, Y.; Zhang, X.; Zhao, Q. Immune-Related Adverse Events Mimicking Behcet's Disease in a Gastric Cancer Patient Following Camrelizumab Treatment. Iran. J. Immunol. 2020, 17, 167-171. [CrossRef]

121. Naidoo, J.; Schindler, K.; Querfeld, C.; Busam, K.; Cunningham, J.; Page, D.B.; Postow, M.A.; Weinstein, A.; Lucas, A.S.; Ciccolini, K.T.; et al. Autoimmune Bullous Skin Disorders with Immune Checkpoint Inhibitors Targeting PD-1 and PD-L1. Cancer Immunol. Res. 2016, 4, 383-389. [CrossRef] [PubMed]

122. Hwang, S.J.; Carlos, G.; Chou, S.; Wakade, D.; Carlino, M.S.; Fernandez-Penas, P. Bullous pemphigoid, an autoantibody-mediated disease, is a novel immune-related adverse event in patients treated with anti-programmed cell death 1 antibodies. Melanoma Res. 2016, 26, 413-416. [CrossRef] [PubMed]

123. Jour, G.; Glitza, I.C.; Ellis, R.M.; Torres-Cabala, C.A.; Tetzlaff, M.T.; Li, J.Y.; Nagarajan, P.; Huen, A.; Aung, P.P.; Ivan, D.; et al. Autoimmune dermatologic toxicities from immune checkpoint blockade with anti-PD-1 antibody therapy: A report on bullous skin eruptions. J. Cutan Pathol. 2016, 43, 688-696. [CrossRef] [PubMed]

124. Sowerby, L.; Dewan, A.K.; Granter, S.; Gandhi, L.; LeBoeuf, N.R. Rituximab Treatment of Nivolumab-Induced Bullous Pemphigoid. JAMA Dermatol. 2017, 153, 603-605. [CrossRef]

125. Haug, V.; Behle, V.; Benoit, S.; Kneitz, H.; Schilling, B.; Goebeler, M.; Gesierich, A. Pembrolizumab-associated mucous membrane pemphigoid in a patient with Merkel cell carcinoma. Br. J. Dermatol. 2018, 179, 993-994. [CrossRef]

126. Wang, X.; Suppa, M.; Bruderer, P.; Sirtaine, N.; Aspeslagh, S.; Kerger, J. A Late Dermatologic Presentation of Bullous Pemphigoid Induced by Anti-PD-1 Therapy and Associated with Unexplained Neurological Disorder. Case Rep. Oncol. 2021, 14, 861-867. [CrossRef] 
127. Sadik, C.D.; Langan, E.A.; Gutzmer, R.; Fleischer, M.I.; Loquai, C.; Reinhardt, L.; Meier, F.; Göppner, D.; Herbst, R.A.; Zillikens, D.; et al. Retrospective Analysis of Checkpoint Inhibitor Therapy-Associated Cases of Bullous Pemphigoid From Six German Dermatology Centers. Front. Immunol. 2020, 11, 588582. [CrossRef]

128. Nishie, W. Update on the pathogenesis of bullous pemphigoid: An autoantibody-mediated blistering disease targeting collagen XVII. J. Dermatol. Sci. 2014, 73, 179-186. [CrossRef]

129. Zhao, C.Y.; Hwang, S.J.E.; Consuegra, G.; Chou, S.; Fernandez-Peñas, P. Anti-programmed cell death-1 therapy-associated bullous disorders: A systematic review of the literature. Melanoma Res. 2018, 28, 491-501. [CrossRef]

130. Yatim, A.; Bohelay, G.; Grootenboer-Mignot, S.; Prost-Squarcioni, C.; Alexandre, M.; Le Roux-Villet, C.; Martin, A.; Maubec, E.; Caux, F. Paraneoplastic Pemphigus Revealed by Anti-programmed Death-1 Pembrolizumab Therapy for Cutaneous Squamous Cell Carcinoma Complicating Hidradenitis Suppurativa. Front. Med. 2019, 6, 249. [CrossRef]

131. Deshpande, R.P.; Sharma, S.; Watabe, K. The Confounders of Cancer Immunotherapy: Roles of Lifestyle, Metabolic Disorders and Sociological Factors. Cancers 2020, 12, 2983. [CrossRef] [PubMed] 